\title{
C9orf72, age at onset, and ancestry help discriminate behavioral from language variants in FTLD cohorts
}

Beatrice Costa, BSc, Claudia Manzoni, PhD, Manuel Bernal-Quiros, PhD, Demis A. Kia, MD, Miquel Aguilar, MD, Ignacio Alvarez, MSc, Victoria Alvarez, PhD, Ole Andreassen, MD, PhD, Maria Anfossi, PhD, Silvia Bagnoli, PhD, Luisa Benussi, PhD, Livia Bernardi, PhD, Giuliano Binetti, MD, Daniel Blackburn, MD, PhD,

Mercè Boada, MD, PhD, Barbara Borroni, MD, Lucy Bowns, Geir Bråthen, MD, PhD, Amalia C. Bruni, MD, Huei-Hsin Chiang, PhD, Jordi Clarimon, PhD, Shuna Colville, MSc, Maria E. Conidi, PhD, Tom E. Cope, MD, PhD, Carlos Cruchaga, PhD, Chiara Cupidi, MD, Maria Elena Di Battista, MD, PhD, Janine Diehl-Schmid, MD, Monica Diez-Fairen, MSc, Oriol Dols-Icardo, PhD, Elisabetta Durante, PhD, Dušan Flisar, MD, Francesca Frangipane, MD, Daniela Galimberti, PhD, Maura Gallo, PhD, Maurizio Gallucci, MD, Roberta Ghidoni, PhD, Caroline Graff, MD, PhD, Jordan H. Grafman, PhD, Murray Grossman, MD, John Hardy, PhD, Isabel Hernández, MD, PhD, Guy J.T. Holloway, MBBS, Edward D. Huey, MD, Ignacio Illán-Gala, MD, PhD, Anna Karydas, MSc, Behzad Khoshnood, PhD, Milica G. Kramberger, MD, PhD, Mark Kristiansen, PhD, Patrick A. Lewis, PhD, Alberto Lleó, MD, PhD, Gaganjit K. Madhan, MSc, Raffaele Maletta, MD, Aleš Maver, MD, PhD, Manuel Menendez-Gonzalez, MD, PhD, Graziella Milan, MD, Bruce Miller, MD, Merel O. Mol, MSc, Parastoo Momeni, PhD, Sonia Moreno-Grau, PhD, Chris M. Morris, PhD, Benedetta Nacmias, PhD, Christer Nilsson, MD, Valeria Novelli, PhD, Linn Öijerstedt, MD,

Alessandro Padovani, MD, Suvankar Pal, MBBS, MRCP, MD, Yasmin Panchbhaya, MSc, Pau Pastor, MD, PhD, Borut Peterlin, MD, PhD, Irene Piaceri, PhD, Stuart Pickering-Brown, PhD, Yolande A.L. Pijnenburg, MD, PhD, Annibale A. Puca, MD, Innocenzo Rainero, MD, PhD, Antonella Rendina, PhD, Anna M.T. Richardson, FRCP, Ekaterina Rogaeva, PhD, Boris Rogelj, PhD, Sara Rollinson, PhD, Giacomina Rossi, PhD, Carola Rossmeier, MD, James B. Rowe, MD, PhD, Elisa Rubino, MD, PhD, Agustín Ruiz, MD, PhD, Raquel Sanchez-Valle, MD, PhD, Sigrid B. Sando, PhD, Alexander F. Santillo, MD, PhD, Jennifer Saxon, MSc, Elio Scarpini, MD,

Maria Serpente, PhD, Nicoletta Smirne, BSc, Sandro Sorbi, MD, EunRan Suh, PhD, Fabrizio Tagliavini, MD, Jennifer C. Thompson, PhD, John Q. Trojanowski, MD, PhD, Vivianna M. Van Deerlin, MD, PhD,

Julie Van der Zee, PhD, Christine Van Broeckhoven, DSc, PhD, Jeroen van Rooij, John C. Van Swieten, MD, Arianna Veronesi, MD, PhD, Emilia Vitale, PhD, Maria L. Waldö, MD, PhD, Cathy Woodward, MSc, Jennifer Yokoyama, PhD, Valentina Escott-Price, PhD, James M. Polke, PhD, and Raffaele Ferrari, PhD, for the International FTD-Genetics Consortium

Neurology ${ }^{\circledR}$ 2020;95:e3288-e3302. doi:10.1212/WNL.0000000000010914

\section{Abstract}

\section{Objective}

We sought to characterize C9orf72 expansions in relation to genetic ancestry and age at onset (AAO) and to use these measures to discriminate the behavioral from the language variant syndrome in a large pan-European cohort of frontotemporal lobar degeneration (FTLD) cases.

\section{Methods}

We evaluated expansions frequency in the entire cohort $(\mathrm{n}=1,396$; behavioral variant frontotemporal dementia $[\mathrm{bvFTD}][\mathrm{n}=800]$, primary progressive aphasia [PPA] $[\mathrm{n}=495]$, and FTLD-motor neuron disease $[\mathrm{MND}][\mathrm{n}=101])$. We then focused on the bvFTD and PPA cases and tested for association between expansion status, syndromes, genetic ancestry, and AAO applying statistical tests comprising Fisher exact tests, analysis of variance with Tukey post hoc tests, and logistic and nonlinear mixed-effects model regressions.

\section{Results}

We found C9orf72 pathogenic expansions in $4 \%$ of all cases (56/1,396). Expansion carriers differently distributed across syndromes: 12/101 FTLD-MND (11.9\%), 40/800 bvFTD (5\%), and 4/495 PPA (0.8\%). While addressing population substructure through principal components analysis (PCA), we defined 2 patients groups with Central/Northern $(\mathrm{n}=873)$ and Southern European $(\mathrm{n}=523)$ ancestry. The proportion of expansion carriers was significantly higher in bvFTD compared to PPA ( $5 \%$ vs $0.8 \%\left[p=2.17 \times 10^{-5}\right.$; odds

\author{
Correspondence \\ Dr. Ferrari \\ r.ferrari@ucl.ac.uk \\ or Dr. Manzoni \\ c.manzoni@ucl.ac.uk
}


ratio (OR) 6.4; confidence interval (CI) 2.31-24.99]), as well as in individuals with Central/Northern European compared to Southern European ancestry (4.4\% vs 1.8\% $\left[p=1.1 \times 10^{-2}\right.$; OR 2.5; CI 1.17-5.99]). Pathogenic expansions and Central/Northern European ancestry independently and inversely correlated with AAO. Our prediction model (based on expansions status, genetic ancestry, and AAO) predicted a diagnosis of bvFTD with $64 \%$ accuracy.

\section{Conclusions}

Our results indicate correlation between pathogenic C9orf72 expansions, AAO, PCA-based Central/Northern European ancestry, and a diagnosis of bvFTD, implying complex genetic risk architectures differently underpinning the behavioral and language variant syndromes.

From the Institute of Neurology (B.C., D.A.K., J.H., P.A.L., R.F.), School of Pharmacy (C.M.), and UCL Movement Disorders Centre (J.H.), University College London; School of Pharmacy (C.M., P.A.L.), University of Reading, Whiteknights; Neurogenetics Laboratory (M.B.-Q., C.W., J.M.P.), National Hospital for Neurology and Neurosurgery, London, UK; Aptima Clinic (Miquel Aguilar), Terrassa; Memory Disorders Unit, Department of Neurology (I.A., M.D.-F., P.P.), University Hospital Mutua de Terrassa, Barcelona; Hospital Universitario Central de Asturias (V.A., M.M.-G.), Oviedo, Spain; NORMENT (O.A.), Institute of Clinical Medicine, University of Oslo, Norway; Regional Neurogenetic Centre (Maria Anfossi, Livia Bernardi, A.C.B., M.E.C., Chiara Cupidi, F.F., Maura Gallo, R.M., N.S.), ASPCZ, Lamezia Terme; Department of Neuroscience, Psychology, Drug Research and Child Health (S.B., B.N., I.P., S.S.), University of Florence; Molecular Markers Laboratory (Luisa Benussi, Giuliano Binetti, R.G.), IRCCS Istituto Centro San Giovanni di Dio Fatebenefratelli, Brescia, Italy; Sheffield Institute for Translational Neuroscience (SITraN), Department of Neuroscience (D.B.), University of Sheffield, UK; Research Center and Memory Clinic (M.B., I.H., S.M.-G., Agustín Ruiz), Fundació ACE, Institut Català de Neurociències Aplicades, Universitat Internacional de Catalunya (UIC), Barcelona, Spain; Centre for Neurodegenerative Disorders (B.B., A.P.), Department of Clinical and Experimental Sciences, University of Brescia, Italy; Department of Clinical Neurosciences (Lucy Bowns, T.E.C., J.B.R.), Cambridge University, UK; Department of Neurology (Geir Bråthen, S.B.S.), University Hospital of Trondheim, Norway; Dept NVS, Division of Neurogeriatrics (H.-H.C., C.G., B.K., L.Ö.), Karolinska Institutet, Bioclinicum Solna, Sweden; Department of Neurology (J.C., O.D.-I., I.I.-G., A.L.), IIB Sant Pau, Hospital de la Santa Creu i Sant Pau, Universitat Autònoma de Barcelona, Spain; Anne Rowling Regenerative Neurology Clinic (S.C., G.J.T.H., S.P.) and Centre for Clinical Brain Sciences (S.P.), University of Edinburgh, UK; NeuroGenomics and Informatics, Department of Psychiatry (Carlos Cruchaga), Washington University, St. Louis, MO; Cognitive Impairment Center (M.E.D.B., Maurizio Gallucci) and Immunohematology and Transfusional Medicine Service (E.D., A.V.), Local Health Authority n.2 Marca Trevigiana, Treviso, Italy; Department of Psychiatry and Psychotherapy (J.D.-S., C.R.), School of Medicine, Technical University of Munich, Germany; Department of Neurology (D.F., M.G.K.) and Clinical Institute of Medical Genetics (A.M., B.P.), University Medical Center Ljubljana, Slovenia; Dino Ferrari Center (D.G., Elio Scarpini, M.S.), University of Milan, Italy; Cognitive Neuroscience Lab, Think and Speak Lab (J.H.G.), Shirley Ryan Ability Lab, Chicago, IL; Department of Pathology and Laboratory Medicine (Murray Grossman, EunRan Suh, J.Q.T., V.M.V.D.), Center for Neurodegenerative Diseases, Perelman School of Medicine at the University of Pennsylvania, Philadelphia; UCL Dementia Research Institute (J.H.), London; Reta Lila Weston Institute (J.H.), UCL Queen Square Institute of Neurology, UK; Institute for Advanced Study (J.H.), The Hong Kong University of Science and Technology, China; Royal Edinburgh Hospital (G.J.T.H.), UK; Taub Institute for Research on Alzheimer's Disease and the Aging Brain (E.D.H.), Columbia University, New York, NY; Department of Neurology, Memory and Aging Center (A.K., B.M., J.Y.), University of California, San Francisco; UCL Genomics (M.K., G.K.M., Y.P.), UCL Great Ormond Street Institute of Child Health, London, UK; Geriatric Center Frullone ASL Napoli 1 Centro (G.M.), Napoli, Italy; Department of Neurology (M.O.M., J.v.R., J.C.V.S.), Erasmus Medical Center, Rotterdam, the Netherlands; Rona Holdings (P.M.), Silicon Valley, CA; Newcastle Brain Tissue Resource, Institute of Neuroscience (C.M.M.), Newcastle University, Campus for Ageing and Vitality, Newcastle upon Tyne, UK; Department of Neurology (C.N.), Skåne University Hospital, Malmö, Sweden; Fondazione Policlinico Universitario A. Gemelli IRCCS (V.N.), Rome, Italy; Division of Neuroscience \& Experimental Psychology (S.P.-B., A.M.T.R., S.R., J.C.T.), University of Manchester, UK; Amsterdam University Medical Center (Y.A.L.P.), VU University Medical Center, the Netherlands; Cardiovascular Research Unit (A.A.P.), IRCCS Multimedica, Milan; Neurology I, Department of Neuroscience (I.R., Elisa Rubino), University of Torino; NeurOMICS laboratory (G.M., Antonella Rendina, E.V.), Institute of Biochemistry and Cell Biology (IBBC), CNR Napoli, Italy; Manchester Centre for Clinical Neurosciences (A.M.T.R., J.S., J.C.T.), Salford Royal NHS Trust, Manchester, UK; Tanz Centre for Research in Neurodegenerative Diseases (Ekaterina Rogaeva), University of Toronto, Canada; Department of Biotechnology (B.R.), Jožef Stefan Institute, Ljubljana, Slovenia; Division of Neurology V and Neuropathology (G.R., F.T.), Fondazione IRCCS Istituto Neurologico Carlo Besta, Milan, Italy; Alzheimer's Disease and Other Cognitive Disorders Unit (R.S.-V.), Hospital Clínic of Barcelona, Spain; Clinical Memory Research Unit, Department of Clinical Sciences Malmö (C.N., A.F.S.), and Division of Clinical Sciences Helsingborg, Department of Clinical Sciences Lund (M.L.W.), Lund University, Sweden; Neurodegenerative Brain Diseases Group (J.V.d.Z., C.V.B.), Center for Molecular Neurology, VIB, Antwerp, Belgium; Medical Research Council Centre for Neuropsychiatric Genetics and Genomics (V.E.-P.), Division of Psychological Medicine and Clinical Neurosciences and Dementia Research Institute, Cardiff University, UK; Instituto de Investigación Sanitaria del Principado de Asturias (V.A.), Oviedo, Asturias; Fundació per la Recerca Biomèdica i Social Mútua Terrassa (I.A., M.D.-F., P.P.), Barcelona; Centro de Investigación Biomédica en Red de Enfermedades Neurodegenerativas (CIBERNED) (M.B., J.C., O.D.-I., I.H., I.I.-G., A.L., S.M.-G., Agustín Ruiz), Instituto de Salud Carlos III, Madrid, Spain; MRC Cognition and Brain Sciences Unit (Lucy Bowns, T.E.C., J.B.R.), Cambridge University, UK; Department of Neuromedicine and Movement Science (Geir Bråthen, S.B.S.), Norwegian University of Science and Technology, Trondheim, Norway; Unit for Hereditary Dementias (H.-H.C., C.G., B.K., L.Ö.), Theme Aging, Karolinska University Hospital, Solna, Sweden; Medical Faculty (D.F., M.G.K.), University of Ljubljana, Slovenia; Fondazione IRCCS Ca'Granda (D.G., Elio Scarpini, M.S.), Ospedale Policlinico, Milan, Italy; Penn Center for Frontotemporal Degeneration (Murray Grossman), Philadelphia, PA; Universidad de Oviedo (M.M.-G.), Asturias, Spain; IRCCS Fondazione Don Carlo Gnocchi (B.N., S.S.), Florence; Istituto di Medicina Genomica (V.N.), Università Cattolica del sacro Cuore, Rome, Italy; Amsterdam Neuroscience (Y.A.L.P.), the Netherlands; Department of Medicine and Surgery (A.A.P.), University of Salerno, Baronissi (SA), Italy; Faculty of Chemistry and Chemical Technology (B.R.), University of Ljubljana, Slovenia; Institud d'Investigacions Biomèdiques August Pi i Sunyer (R.S.-V.), Barcelona, Spain; Department of Biomedical Sciences (J.V.d.Z., C.V.B.), University of Antwerp, Belgium; and Department of Comparative Biomedical Sciences (P.A.L.), The Royal Veterinary College, London, UK.

International FTD-Genetics Consortium (IFGC) coinvestigators are listed at links.Iww.com/WNL/B240.

Go to Neurology.org/N for full disclosures. Funding information and disclosures deemed relevant by the authors, if any, are provided at the end of the article.

The Article Processing Charge was funded by MRC and Wellcome Trust.

This is an open access article distributed under the terms of the Creative Commons Attribution License 4.0 (CC BY), which permits unrestricted use, distribution, and reproduction in any medium, provided the original work is properly cited. 


\section{Glossary}

AAO = age at onset; bvFTD $=$ behavioral variant frontotemporal dementia; FTLD $=$ frontotemporal lobar degeneration; IFGC = International FTD Genetics Consortium; LOOCV = leave-one-out cross-validation; MND = motor neuron disease; PCA = principal components analysis; PNFA = progressive nonfluent aphasia; PPA = primary progressive aphasia; $\mathbf{r c}=$ repeat counts; SNP = single nucleotide polymorphism.

Frontotemporal lobar degeneration (FTLD) refers to the second most common form of young-onset dementia after Alzheimer disease. ${ }^{1}$ The major clinical syndromes are behavioral variant frontotemporal dementia $(\text { bvFTD })^{2}$ or language dysfunctions, broadly called primary progressive aphasia (PPA); the latter is subdivided into semantic dementia or semantic variant PPA and progressive nonfluent aphasia (PNFA) or nonfluent/agrammatic variant PPA. ${ }^{2,3}$ FTLD can also occur together with motor neuron disease (MND) or amyotrophic lateral sclerosis in a continuous spectrum of phenotypes. ${ }^{4}$

In FTLD, repeat expansions in $C 9$ orf $72^{5}$ have been previously reported to occur in $\sim 25 \%{ }^{6-10}$ of familial and $\sim 6 \%{ }^{11}$ of sporadic cases (i.e., individuals with no clear familial history or genetic aetiology $\left.y^{12}\right)$. Several studies had shown high frequencies of pathogenic C9orf72 expansions in Northern vs Southern European patients (North-South axis), especially in historically isolated populations (such as the Finnish ${ }^{13,14}$ ), leading to the hypothesis that a Scandinavian founder might be at the basis of the spread of the C9orf 72 expansion. ${ }^{15}$ Other studies (based on the geographic location of the recruiting sites) challenged the North-South axis concept, reporting a high frequency $(\sim 25 \%)$ of pathogenic expansions in the Spanish population ${ }^{10}$ or implying to the existence of more than 1 risk haplotype. ${ }^{16-19}$

Patients with FTLD with abnormal C9orf72 repeat expansions exhibit marked phenotypic and pathologic heterogeneity, suggesting presence of additional (genetic and environmental) modifiers. ${ }^{20}$ Despite conflicting studies reporting either direct or inverse correlation between repeat length and age at onset (AAO), C9orf 72 expansions have been suggested to act as a genetic modifier of AAO. ${ }^{16,21-24}$

We analyzed 1,396 FTLD cases gathered through the International FTD Genetics Consortium (IFGC) (ifgcsite.wordpress.com/) phase III initiative, aiming at (1) characterizing C9orf72 expansions in relation to genetic ancestry and AAO and (2) assessing the usefulness of these measures in discriminating the behavioral from the language variant syndrome.

\section{Methods}

\section{Standard protocol approvals, registrations, and patient consents}

Each contributing site obtained written informed consent from all patients to be part of extended genetic studies; the current study is approved under institutional review board approval 9811/001.

\section{Cohort, clinical phenotyping}

FTLD cases were collected between 2016 and 2018 (within the IFGC phase III project [ifgcsite.wordpress.com/ongoing-projects/]). The samples were recruited by clinicians and research groups who are part of the IFGC network and based in Italy, Spain, Germany, the Netherlands, Belgium, the United Kingdom, Sweden, Norway, Slovenia, or the United States (supplementary table 1, doi.org/10.5522/ 04/12418157). Patients were diagnosed at each contributing site (supplementary table 2, doi.org/10.5522/04/ 12418157) in a harmonized fashion according to international consensus criteria such as those of Neary et al. ${ }^{2}$ (for FTLD), Rascovsky et al. ${ }^{25}$ (for bvFTD), GornoTempini et al. ${ }^{3}$ (for PPA [semantic dementia or PNFA]), and Strong et al. ${ }^{4}$ (for FTLD-MND).

\section{Genotyping, C9orf72 repeat expansions, and analysis cohorts}

A total of 1,454 cases were successfully genotyped by means of the NeuroArray ${ }^{26}$ on the Illumina Infinium platform. Genotypes were used to inform on population substructure via standard principal components analysis (PCA) (supplementary figure 1 , doi.org/10.5522/04/12418157), which led to the exclusion of 44 population outliers, and allowed us to address population substructure within the cohort (we identified 2 distinct [Nordic and Mediterranean] clusters; supplementary figure 2, doi.org/10.5522/04/12418157). We also assessed cryptic relatedness and excluded 14 first- or second-degree related individuals, leaving a cohort of 1,396 cases (group $0)$-for which C9orf72 expansion status (i.e., presence/ absence of pathogenic expansions) was known-for analyses. Frequencies of pathogenic expansions were assessed in group 0 and further analyses were performed in (1) 1,295 cases (group 1: $\mathrm{n}=800$ bvFTD and $\mathrm{n}=495 \mathrm{PPA}$ ) with known C9orf72 expansion status; (2) 1,179 cases (group 2; $\mathrm{n}=756$ bvFTD and $n=423 \mathrm{PPA}$ ) with known C9orf72 expansion status and AAO data available; and (3) 734 cases (group 3; n = 462 bvFTD and $n=272 \mathrm{PPA}$ ) with $\mathrm{AAO}$ and repeat counts (rc; screened via repeat-primed PCR) (see references 27 and 28; supplementary Methods and supplementary figure 3, doi. org $/ 10.5522 / 04 / 12418157$; and figure $1 \mathrm{~A}$ ).

\section{Statistical analyses}

We first assessed the frequency of pathogenic expansions in the entire cohort (group 0 ). The information on presence/absence of expansions was used as a binary variable $(0=$ absence of 


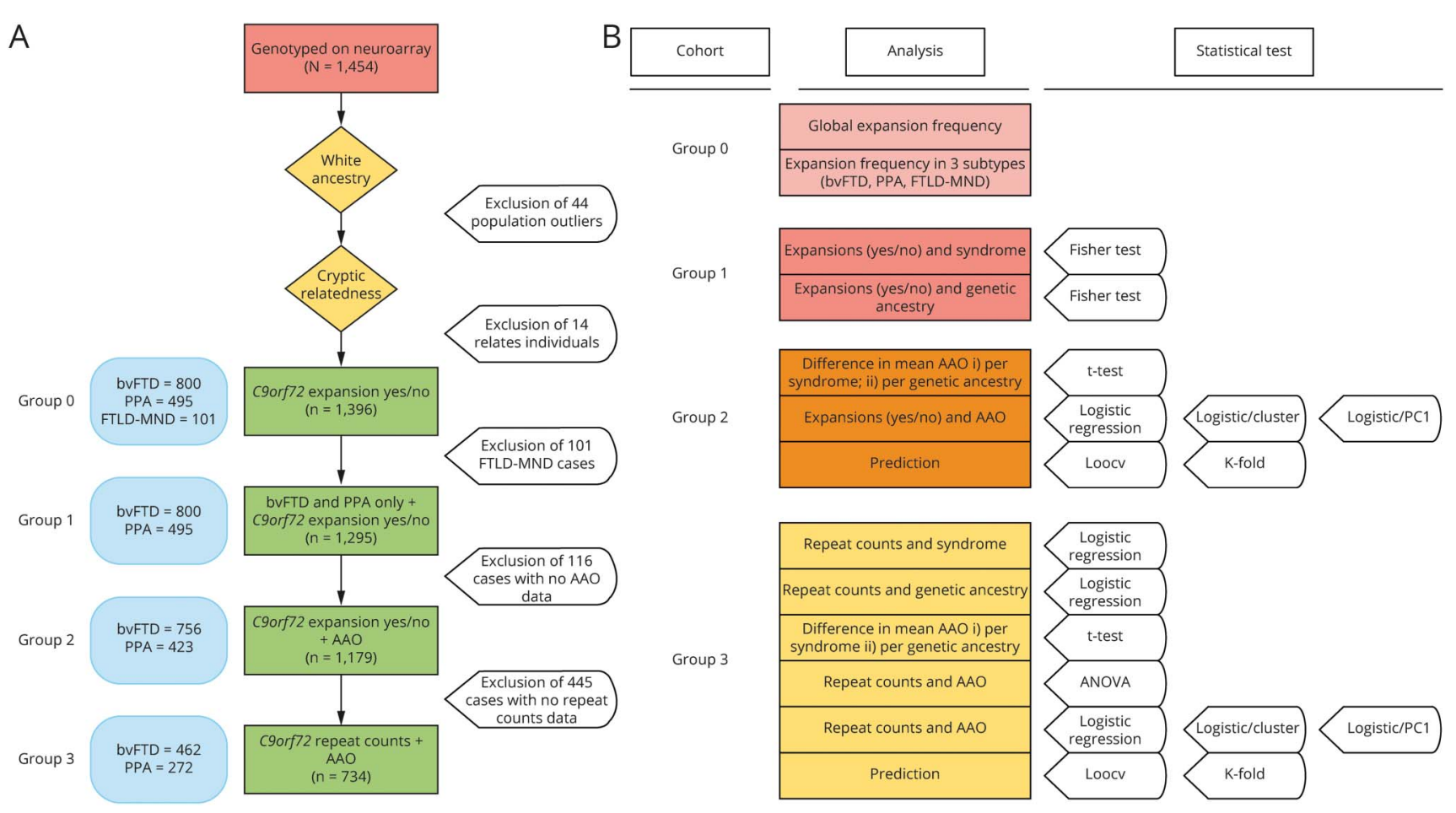

(A) Cohorts. (B) Analysis workflow. K-fold regression model. AAO = age at onset; ANOVA = analysis of variance; bvFTD = behavioral variant frontotemporal dementia; FTLD = frontotemporal lobar degeneration; logistic/cluster = logistic regression using cluster as covariate; logistic/PC1 = logistic regression using PC1 as covariate; LOOCV = leave-one-out cross-validation regression model; MND = motor neuron disease; PPA = primary progressive aphasia.

expansion; 1 = presence of expansion). We then investigated differences in the frequencies of pathogenic expansions across bvFTD and PPA and the Nordic and Mediterranean clusters in group 1 (Fisher exact test) and in group 3 (logistic regression); in the latter, we used rc as a categorical variable (using no, short, intermediate, and long as factor levels) considering the following 4 categories: no expansions $(\mathrm{rc}=2 / 3)$, short expansions $(4 \leq \mathrm{rc} \leq 8)$, intermediate expansions $(9 \leq \mathrm{rc} \leq 24)$, and long expansions ( $\mathrm{rc} \geq 25$ ), the latter representing expansions in the pathogenic range (see references 10 and 22, supplementary Methods, and supplementary figure 3, doi.org/10.5522/04/ 12418157).

We then evaluated association between AAO and syndrome, genetic ancestry, and expansions (i.e., presence/absence used as a binary variable; see above) alone and with genetic ancestry as a covariate in group 2 ( $t$ test and logistic regression) and in group 3 ( $t$ test, analysis of variance with Tukey post hoc test, and logistic and linear mixed-effects model). In the latter case, we used rc as a categorical variable (see above).

Finally, we sought to build a model to predict syndrome (bvFTD vs PPA) using (1) presence/absence of pathogenic expansions (as binary variable [see above] for group 2) or (2) rc (as categorical variable [see above] for group 3), ancestry as binary variable, and $\mathrm{AAO}$ as continuous variable using logistic regression models (i.e., the leave-one-out cross-validation
[LOOCV] and the K-fold models). A summary of the analyses workflow can be found in figure 1B.

All analyses were performed using R studio (version 3.6.0, studio version 1.2.1335).

\section{C9orf72 locus risk haplotype}

Twenty (rs1110264, rs1110155, rs2150336, rs1161680, rs2589054, rs1822723, rs4879515, rs895023, rs868856, rs1977661, rs903603, rs12349820, rs10122902, rs2282241, rs1948522, rs 1982915, rs2453556, rs702231, rs696826, and rs247751) of the original 42 single nucleotide polymorphisms (SNPs) constituting the (Finnish) risk haplotype ${ }^{29}$ were available on the NeuroArray. ${ }^{26}$ We filtered out 7 markers in order to keep 13 informative SNPs (rs1822723, rs4879515, rs868856, rs1977661, rs903603, rs10122902, rs2282241, rs1948522, rs1982915, rs2453556, rs702231, rs696826, and rs2477518) matching 13 of the 20 used in Mok et al. ${ }^{15}$ We evaluated the proportion of cases carrying at least 1 risk allele (as in Mok et al. ${ }^{15}$ ) for each marker assessing expansion vs nonexpansion carriers (with/without ancestry stratification).

\section{Data availability}

All data generated or analyzed during this study are included in this published article and supplementary files 1 and 2 at doi. org/10.5522/04/12418157. 


\section{Results}

\section{C9orf72 expansions frequency and syndromes}

We assessed the frequency of pathogenic expansions in the entire cohort and across the different syndromes in the group 0 cases (figure 1). Four percent of all cases (56/1,396 [4\%]) carried pathogenic expansions. These were most frequent in FTLD-MND (12/101 [11.9\%]) followed by bvFTD (40/800 [5\%]) and PPA (4/495 [0.8\%]). The higher prevalence of pathogenic expansions in bvFTD vs PPA was statistically significant (Fisher exact test: $p=2.17 \times 10^{-5}$; OR 6.4; $95 \% \mathrm{CI}$ 2.31-24.99, table 1). We further explored this finding in the group 3 cases using logistic regression to assess association between expansion length (represented by $4 \mathrm{rc}$ factor levels: short, intermediate, and long expansions, tested against no expansions) and syndromes (bvFTD vs PPA). Expansion length discriminated bvFTD from PPA with a trend that was significant in the intermediate $\left(p=4.7 \times 10^{-2}\right.$; OR 1.6; CI $0.0061[2.5 \%]-0.94[97.5 \%])$ and long $\left(p=1.9 \times 10^{-3}\right.$; OR 7.2; CI $0.86[2.5 \%]-3.45[97.5 \%]$ ) rc ranges (with a $\sim 90 \%$ probability of a bvFTD diagnosis supported by the latter; supplementary table 3, doi.org/10.5522/04/12418157).

\section{C9orf72 expansions (and rc) and genetic ancestry}

We performed PCA (PC1 vs PC2, supplementary figure 2A; $\mathrm{PC} 1$ vs $\mathrm{PC} 3$, supplementary figure $2 \mathrm{~B}$, doi.org/10.5522/04/ 12418157) to cluster the group 1 cases based on their genetic makeup. There were 2 major clusters: cluster 1 (Mediterranean) included most of the cases (439/500 [87.8\%]) recruited from Southern European sites (Italy and Spain); cluster 2 (Nordic) included most of the cases (627/795 $[78.8 \%]$ ) recruited from Central and Northern European sites (Belgium, the Netherlands, Germany, the United Kingdom, Norway, and Sweden). Samples recruited from Eastern European (Slovenia) and North American sites distributed across both clusters, although with a higher prevalence within cluster $2(167 / 795[21 \%])$ vs cluster $1(42 / 500[8.4 \%])$.

Table 1 Frequency of expansion carriers in the entire cohort and by syndrome

\begin{tabular}{llll}
\hline Cohort & Cases, $\mathbf{n}$ & Expansion carriers & Frequency, \% \\
\hline bvFTD & 800 & 40 & $5^{\mathrm{a}}$ \\
\hline PPA & 495 & 4 & $0.8^{\mathrm{a}}$ \\
\hline FTLD-MND & 101 & 12 & 11.9 \\
\hline Total & 1,396 & 56 & 4
\end{tabular}

Abbreviations: bvFTD = behavioral variant frontotemporal dementia; FTLD = frontotemporal lobar degeneration; $\mathrm{MND}=$ motor neuron disease; PPA = primary progressive aphasia.

Summary of expansion carrier frequency in the entire cohort $(n=1,396)$ and across syndromes. The higher prevalence of expansion carriers in bvFTD vs PPA is statistically significant: ${ }^{a}$ Fisher exact test performed to statistically evaluate the difference between the occurrence of pathogenic expansions in bvFTD vs PPA: $p=2.17 \times 10^{-5}$; odds ratio $6.4 ; 95 \%$ confidence interval 2.31-24.99.
Table 2 Frequency of expansion carriers in the Nordic and Mediterranean clusters

\begin{tabular}{llll}
\hline Genetic ancestry & Cases, $\mathbf{n}$ & Expansion carriers & Frequency, \% \\
\hline Nordic & 795 & 35 & $4.4^{\mathrm{a}}$ \\
\hline Mediterranean & 500 & 9 & $1.8^{\mathrm{a}}$ \\
\hline
\end{tabular}

The higher prevalence of expansion carriers in the Nordic vs the Mediterranean cluster is statistically significant: ${ }^{\mathrm{a}}$ Fisher exact test: $p=1.1 \times 10^{-2}$; odds ratio 2.5; 95\% confidence interval 1.17-5.99.

We observed a significantly higher prevalence of pathogenic expansions in the Nordic $(35 / 795[4.4 \%])$ vs the Mediterranean $(9 / 500[1.8 \%])$ cluster (Fisher exact test: $p=1.1 \times$ $10^{-2}$; OR 2.5; CI 1.17-5.99, table 2). We further evaluated this finding in the group 3 cases using logistic regression to assess association between expansion length (see above) and genetic ancestry. Expansion length discriminated the Nordic from Mediterranean cluster with a trend that was significant in the intermediate $\left(p=9.7 \times 10^{-4}\right.$, OR 2.2; CI $0.32[2.5 \%]-1.25$ [97.5\%]) and long $\left(p=4.7 \times 10^{-4}\right.$, OR 9.3; CI 1.12 [2.5\%]-3.7 [97.5\%]) rc ranges (with a $\sim 90 \%$ probability of Nordic ancestry supported by the latter; supplementary table 4, doi.org/10.5522/04/12418157).

Provided differences in syndromes prevalence and distribution across the Nordic and Mediterranean clusters-bvFTD $(469 / 795$ [59\%] vs $331 / 500$ [66.2\%]) and PPA (326/795 [41\%] vs $169 / 500$ [33.8\%]), respectively (supplementary table 5, doi.org/10.5522/04/12418157) —we analyzed the distribution of pathogenic expansions across syndromes and clusters. Stratified Fisher exact test showed significant differences in the distribution of the pathogenic expansions between bvFTD and PPA in the Nordic (but not the Mediterranean) cluster $\left(p=1 \times 10^{-4}\right.$; OR $7.87 ; 95 \% \mathrm{CI}$ 2.43-40.52), and between the Nordic and the Mediterranean clusters for the bvFTD (but not PPA) syndrome $(p=1.9 \times$ $10^{-2}$; OR 2.95 ; $95 \%$ CI $\left.1.31-7.52\right)$, suggesting that ancestry (Nordic) and syndrome (bvFTD) are independently associated with pathogenic expansions (table 3 ).

\section{C9orf72 repeat expansions (and counts [rc]) and AAO}

We assessed AAO in the group 2 cases (figure 1). Mean AAO was significantly different between the bvFTD (61.7) and PPA (64) syndromes ( $t$ test: $p=1.86 \times 10^{-5}$; CI -3.34 to $-1.25)$ and the Nordic (61.3) and Mediterranean (64.3) clusters ( $t$ test: $p=1.16 \times 10^{-7}$; CI 1.86-4.03) (figure $2 \mathrm{~A}$ and supplementary table $6, \mathrm{~A}$ and $\mathrm{B}$, doi.org/10.5522/04/ 12418157). We then assessed the relationship between pathogenic expansions and AAO via logistic regression. First, we identified a significant correlation between a decrease in $\mathrm{AAO}$ and presence of pathogenic expansions $\left(p=7.7 \times 10^{-4}\right.$; $R^{2}=0.008 ; \mathrm{CI}-8.05[2.5 \%]$ to $\left.-2.13[97.5 \%]\right)$. When we included genetic ancestry in the model, we observed a significant correlation with a decrease in $\mathrm{AAO}$, with no difference 
Table 3 Stratified Fisher exact tests comparing prevalence of pathogenic expansions across behavioral variant frontotemporal dementia (bvFTD) and primary progressive aphasia (PPA) and the Nordic and Mediterranean clusters

\begin{tabular}{|c|c|c|c|}
\hline & \multicolumn{2}{|c|}{ Expansion range } & \multirow[b]{2}{*}{ Fisher exact test } \\
\hline & Pathogenic & Nonpathogenic & \\
\hline \multicolumn{4}{|l|}{ Subtype/ancestry } \\
\hline \multicolumn{4}{|l|}{ bvFTD } \\
\hline Mediterranean & 8 & 323 & $p=1.9 \times 10^{-2 a}$ \\
\hline Nordic & 32 & 437 & \\
\hline \multicolumn{4}{|l|}{ Ancestry/subtype } \\
\hline \multicolumn{4}{|l|}{ Mediterranean } \\
\hline bvFTD & 8 & 323 & $p=1$ \\
\hline PPA & 1 & 168 & \\
\hline \multicolumn{4}{|l|}{ Nordic } \\
\hline bvFTD & 32 & 437 & $p=1 \times 10^{-4 b}$ \\
\hline PPA & 3 & 323 & \\
\hline \multicolumn{4}{|c|}{$\begin{array}{l}p \text { Values presented in the table are corrected for multiple testing statistics. Prior correction } p \text { values were as follows: }{ }^{\text {a }} \text { (uncorrected) Fisher exact test: } p=4.7 \times \\
10^{-3} \text {; odds ratio } 2.95 ; 95 \% \text { confidence interval } 1.31-7.52 \text { : significant difference in the prevalence of bvFTD expansion carriers in the Nordic vs the } \\
\text { Mediterranean cluster; }{ }^{b} \text { (uncorrected) Fisher exact test } p=2.7 \times 10^{-5} \text {; odds ratio 7.87; } 95 \% \text { confidence interval } 2.43-40.52: \text { significant difference in the } \\
\text { prevalence of expansion carriers in bvFTD vs PPA within the Nordic cluster. }\end{array}$} \\
\hline
\end{tabular}

in using either cluster $\left(p=2.3 \times 10^{-3} ; \mathrm{CI}-7.5[2.5 \%]\right.$ to -1.63 [97.5\%] for pathogenic expansions; $p=2.3 \times 10^{-7}$; CI -3.9 $[2.5 \%]$ to $-1.77[97.5 \%]$ for cluster; $\left.R^{2}=0.03\right)$ or PC1 $(p=$ $2.1 \times 10^{-3} ; \mathrm{CI}-7.5[2.5 \%]$ to $-1.66[97.5 \%]$ for pathogenic expansions; $p=6.4 \times 10^{-7}$; CI 30.1 [2.5\%]-68.9 [97.5\%] for PC1; $\left.R^{2}=0.028\right)$ as covariate and an almost 4-fold goodness of fit increase (supplementary table 7, A-C, doi.org/10.5522/ 04/12418157). Of note, when comparing the 2 regression models (with/without genetic ancestry as covariate) through the $\log$-likelihood $R^{2}$ ratio test, the difference (between the 2 models) appeared not to be due to chance $\left(p<10^{-12}\right)$ (supplementary table $7, \mathrm{~B}$ and $\mathrm{C}$, doi.org/10.5522/04/ 12418157).

We further evaluated the relationship between expansion length (represented by $4 \mathrm{rc}$ factor levels-short, intermediate, and long expansions, tested against no expansions) and AAO in the group 3 cases (figure 1). First, we independently analyzed association between AAO and (1) genetic ancestry-mean AAO 60.9 and 64.6 in the Nordic and Mediterranean cluster, respectively $(t$ test: $p=2.1 \times$ $10^{-7}$; CI 2.32-5.09; supplementary table $8 \mathrm{~A}$, doi.org/10. 5522/04/12418157); (2) syndrome-mean AAO 61.7 and 63.5 in the bvFTD and PPA syndromes, respectively ( $t$ test: $p=9.1 \times 10^{-3}$; CI -3.11 to -0.44 ; supplementary table 8B, doi.org/10.5522/04/12418157), and (3) expansion length-mean AAO 63.2 for both no and short expansions, 61 for intermediate expansions, and 58 for long expansions (analysis of variance $p=3.6 \times 10^{-2}$; CI -10.2 to
-0.23 for long vs no expansions) (supplementary table $8 \mathrm{D}$, figure $2 \mathrm{~B}$ and $\mathrm{C}$ : doi.org/10.5522/04/12418157). We then assessed the relationship between expansion length (see above) and AAO via logistic regression. First, we identified a significant correlation between a decrease in $\mathrm{AAO}$ and both intermediate and long expansions $\left(p=4 \times 10^{-2}\right.$; CI -4.36 $[2.5 \%]$ to $-0.96[97.5 \%]$ for intermediate and $\mathrm{p}=7 \times 10^{-3}$; CI $-9.05[2.5 \%]$ to $-1.43[97.5 \%]$ for long expansions; $R^{2}=$ 0.017) (supplementary table 9A, doi.org/10.5522/04/ 12418157). When we included genetic ancestry in the model, we observed a significant correlation with a decrease in $\mathrm{AAO}$, no difference in using either cluster $(p=4.7 \times$ $10^{-2}$; CI $-7.65[2.5 \%]$ to -0.05 [97.5\%] for long vs no expansion; $p=2.38 \times 10^{-6}$; CI -4.73 [2.5\%] to -1.97 [97.5\%] for cluster; $\left.R^{2}=0.045\right)$ or PC1 $\left(p=5.98 \times 10^{-2}\right.$; CI -7.5 [2.5\%] to 0.14 [97.5\%] for long vs no expansion; $p=$ $1.2 \times 10^{-6}$; CI $39.8[2.5 \%]-92.9[97.5 \%]$ for PC1; $R^{2}=$ 0.047 ) as covariate and an almost 3 -fold goodness of fit increase (supplementary table 9, A-C, doi.org/10.5522/ $04 / 12418157)$. Of note, when comparing the 2 regression models (with/without genetic ancestry as covariate) through the log-likelihood $R^{2}$ ratio test, the difference (between the 2 models) appeared not to be due to chance $\left(p<10^{-12}\right)$ (supplementary table 9, B and C, doi.org/10. $5522 / 04 / 12418157)$. These findings were further supported by nonlinear mixed-effects model regression using genetic ancestry as random effect covariate (for long vs no expansion; see supplementary table 10, doi.org/10.5522/ 04/12418157). 

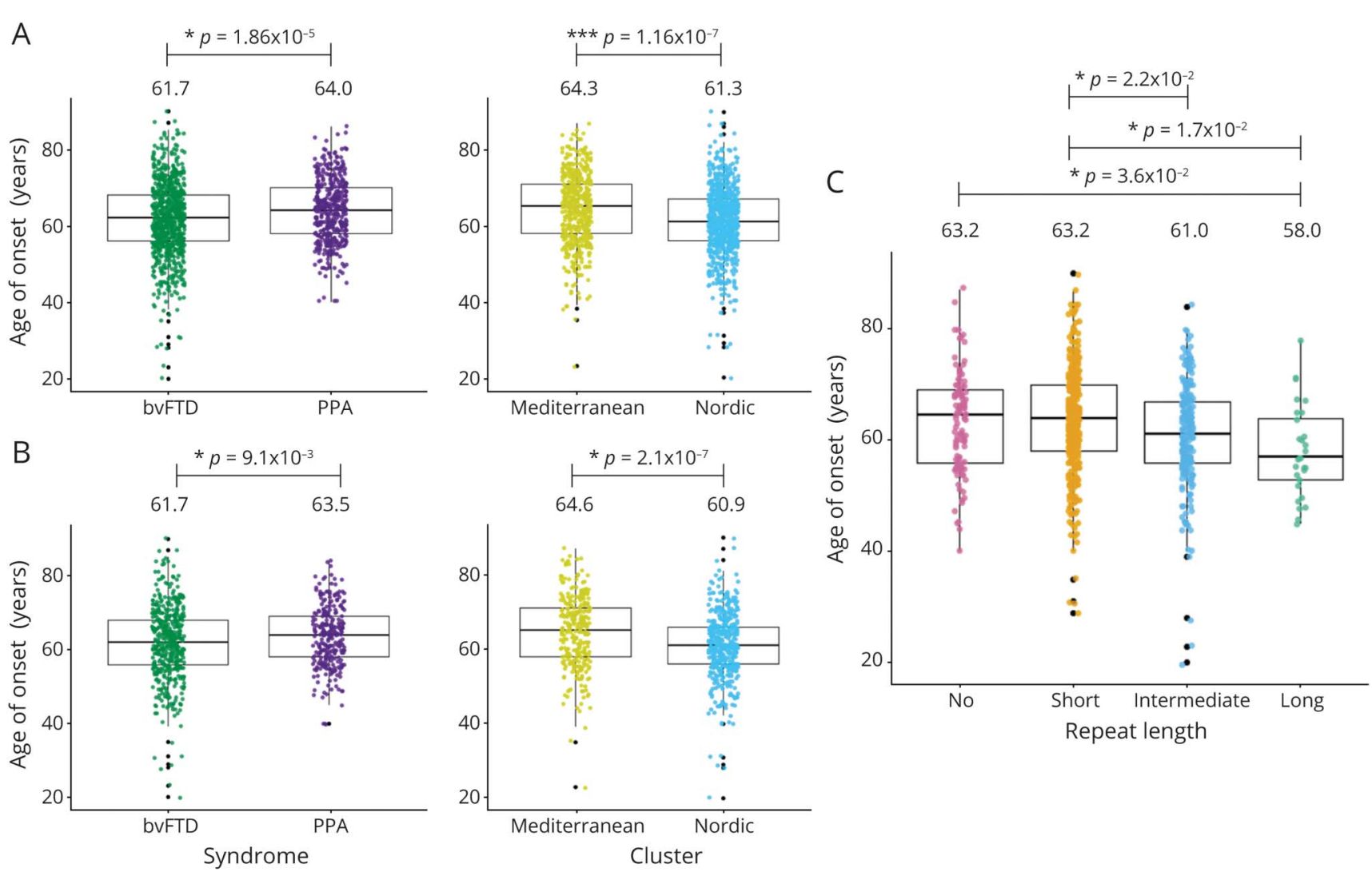

(A) AAO in the group 2 cases. Mean AAO behavioral variant frontotemporal dementia (bvFTD) (61.7) and primary progressive aphasia (PPA) (64) $(t$ test: $p=1.86$ $\times 10^{-5}$; confidence interval [CI] -3.34 to 1.25); mean AAO Nordic (61.3) and Mediterranean (64.3) clusters ( $t$ test: $\left.p=1.16 \times 10^{-7} ; \mathrm{Cl} 1.86-4.03\right)$. (B) AAO in the group 3 cases. Mean AAO bvFTD (61.7) and PPA (63.5) ( $t$ test: $p=9.1 \times 10^{-3} \cdot \mathrm{Cl}-3.11$ to 0.44$)$; mean AAO Nordic (60.9) and Mediterranean (64.6) ( $t$ test: $p=2.1 \times$ $10^{-7} ; \mathrm{Cl} 2.32-5.09$ ). (C) AAO in the group 3 cases. Mean AAO for both no and short expansions (63.2), for intermediate expansions (61), and for long expansions (58) evaluated via analysis of variance test.

\section{C9orf72 locus risk haplotype}

All of the risk alleles for the 13 markers-shortest informative stretch of the original risk haplotype ${ }^{15,29}$ available to us-were seen in (1) 40/56 (71.4\%) expansion carriers vs $380 / 1,340$ (28.4\%) nonexpansion carriers in the entire cohort; (2) 33/47 (70.2\%) expansion carriers vs 228/826 (27.6\%) nonexpansion carriers in the Nordic cluster; and (3) 7/9 (77.8\%) expansion carriers vs $152 / 514$ (29.6\%) nonexpansion carriers in the Mediterranean cluster. Comparing the proportion of risk allele carriers (expansion vs nonexpansion carriers) for each single marker, 5/13 markers (rs4879515, rs868856, rs903603, rs2282241, rs2453556) were significant in the Nordic cluster, and none in the Mediterranean cluster (supplementary figure 4, doi. org/10.5522/04/12418157). Rs2477518 showed variable frequencies for the risk allele ( $\mathrm{T})$ across expansion vs nonexpansion carriers (and the 2 clusters), thus making this most probably a negligible marker within this stretch, as hinted previously. ${ }^{15,17}$ Rs3849942, previously suggested as a surrogate marker for the risk haplotype, ${ }^{15}$ was not among the SNPs available to us. We used rs868856, displaying strongest linkage disequilibrium with rs3849942 (D' $=0.96 ; R^{2}=0.7$; ldlink.nci.nih.gov/), as informative proxy: the risk allele segregated differently across expansion vs nonexpansion carriers in the Nordic and Mediterranean cluster (as for rs2453556), possibly suggesting these 2 as the most conserved markers of the original risk haplotype across populations in expansion carriers (highlighted in blue in supplementary figure 4, doi.org/10.5522/ 04/12418157).

\section{Syndrome prediction}

We then sought to build a model to predict syndrome (bvFTD vs PPA) and assess its accuracy. We analyzed both groups 2 and 3 cases using expansion status (presence/ absence of expansion for group 2 and the $4 \mathrm{rc}$ factor levels for group 3 [see Methods]), genetic ancestry (using either cluster or $\mathrm{PC} 1$ ) as binary variables, and AAO as a continuous variable in logistic regression models. We observed an accuracy of $\sim 0.64$ (group 2; supplementary table 11, doi.org/10.5522/04/12418157) and $\sim 0.62$ (group 3; supplementary table 12, doi.org/ $10.5522 / 04 / 12418157)$ in predicting bvFTD; there were no differences in the outcome when using either cluster or PC1 as covariates in both (LOOCV and K-fold) models. 


\section{Discussion}

This study aimed to characterize C9orf72 expansions in relation to genetic ancestry and AAO and to assess the usefulness of these measures in discriminating the behavioral from the language variant syndrome in a large pan-European cohort of 1,396 FTLD cases.

To our knowledge, the current work is unique in that, prior to characterizing the expansions, we excluded populationsubstructure bias using genome-wide genotyping data to cluster the cases on the basis of their genetic makeup. After PCA, we identified 2 distinct clusters including samples with geographic ancestry corresponding to Southern Europe (Mediterranean cluster) and Central/Northern Europe (Nordic cluster). Our analyses not only showed that patients from the Nordic cluster presented significantly higher frequency of pathogenic C9orf72 expansions compared to the Mediterranean cluster, but also that a core stretch of markers $(n=8)$ of the Finnish risk haplotype ${ }^{29}$ appeared to be conserved across the Nordic expansion carriers, whereas there was a similar tendency for (just) 2 of such markers in the Mediterranean expansion carriers. Several studies had shown high frequencies of long C9orf72 expansions in Northern vs Southern European patients (North-South axis). ${ }^{13-15}$ Other studies (based on the geographic location of the recruiting sites) challenged the North-South axis concept, ${ }^{10}$ or the founder effect implying the existence of more than 1 risk haplotype. ${ }^{16-19}$ All this taken together, our current data appear to support the North-South axis hypothesis and suggest that rearrangements (and instability) ${ }^{16,19}$ at the C9orf 72 locus might have occurred, reducing the level of conservation of the original risk haplotype across the European population.

We found pathogenic expansions in $\sim 4 \%$ of all cases and that the proportion of expansion carriers was significantly higher in bvFTD compared to PPA. The fact that we overall identified significant association between pathogenic expansions and a diagnosis of bvFTD and Central/Northern European ancestryfindings in line with previous reports ${ }^{8,10,13,20,30-34}$ — suggests that C9orf72 expansions might serve as useful genetic fingerprint to define subpopulations of FTLD (figure 3). Of note, we observed a trend of association with syndrome (bvFTD) and genetic ancestry (Central/Northern European) already supported by the intermediate repeat counts $(9 \leq \mathrm{rc} \leq 24)$ category. This appears in line with previous reports suggesting that individuals with 7-24 alleles might have an increased risk to convert to carriers of pathologic repeat expansions ${ }^{10,22}$ and may, altogether, be useful information in the context of diagnostics.

Despite some previous conflicting reports of direct (or inverse) correlation between C9orf72 expansions and $\mathrm{AAO},{ }^{16,21,23}$ we (as others ${ }^{22,24}$ ) found a significant inverse correlation between $\mathrm{C} 9$ orf 72 expansion length and $\mathrm{AAO}$. In addition, and interestingly, our data also indicate that Central/Northern European genetic ancestry contributes to a decreased AAO (independently from the expansions),
Figure 3 Patient subpopulations (behavioral variant frontotemporal dementia [bvFTD] and primary progressive aphasia [PPA] syndromes) based on C9orf72 expansion genetic signatures and ancestry

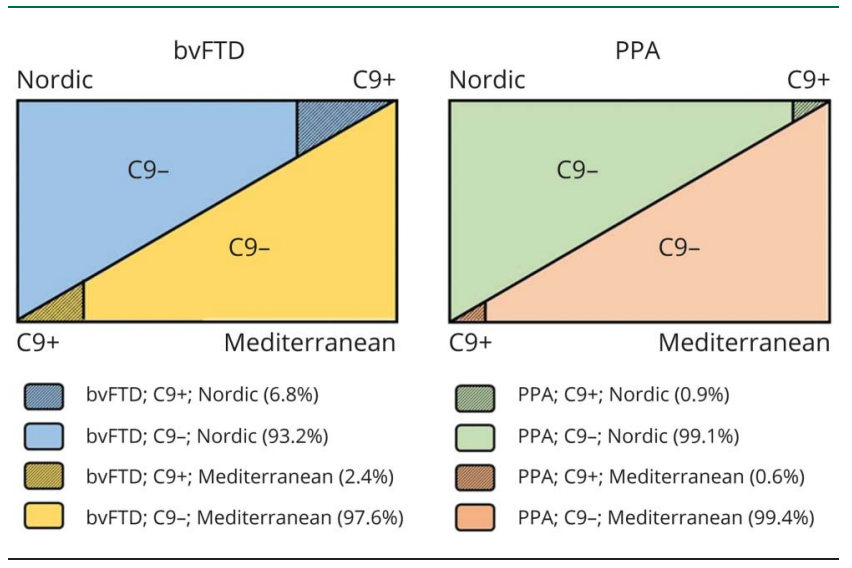

possibly implying a more complex genetic signature (or architecture), and subsequently molecular mechanisms, underpinning this feature. Clearly, disease mechanisms that involve C9orf72 expansion length and AAO are complex, thus it is likely that additional factors might further modulate their relationship and effect on the phenotype (see also Babić Leko et al. ${ }^{5}$.

While using expansion length, genetic ancestry, and AAO in a regression model to discriminate behavioral from language variant subtypes, we found that such measures supported a prediction of bvFTD with $64 \%$ accuracy.

Our results have a number of implications. First, provided that significant variation exists in the genetic architecture of the Caucasian population, ${ }^{35}$ genetic variability characterizing and differentiating Nordic vs Mediterranean subjects (such as in the case of our cohort) might influence predisposition to harboring longer repeat expansions. In other repeat expansion diseases-e.g., Huntington disease or other microsatellite diseases, including myotonic dystrophy and spinocerebellar ataxias $^{35}$ - the presence of specific haplogroups in Western European populations occurs with a manifold increase in prevalence of repeats compared to other ethnic groups and populations. ${ }^{36}$ Second, different genetic risk architectures underpinning different (and possibly genetically more homogeneous) subpopulations of patients may exist within the FTLD population.

In a nutshell, our results imply that a significantly higher proportion of FTLD cases, with Nordic rather than Mediterranean genetic ancestry, is likely to develop bvFTD in presence of intermediate and long (pathogenic) expansions, whereas long (pathogenic) expansions are (almost) negligible in PPA, regardless of ancestry. Clearly, multiple factors including genetic heterogeneity, epigenetic changes, ethnicity, as well as environmental factors 
and habits that may subsist within and across multicultural cohorts, all together, contribute to disease predisposition, onset, and progression. ${ }^{22,37,38}$ These concepts, reinforced by our study, warrant further characterization of genetic, environmental, and additional clinical measures to finetune models able to predict disease outcome to complement diagnostic criteria, and possibly assist in the identification of informative cohorts for tailored clinical trials and the development of effective personalized therapies.

\section{Acknowledgment}

The authors thank the patients and their families and the IFGC (ifgcsite.wordpress.com/) phase III network.

\section{Study funding}

R. Ferrari and B. Costa are supported by funding from the Alzheimer's Society (grants 284 and 447). V. Alvarez and M. Menendez-Gonzalez are supported by the Fondos Feder (grant PI 15/00878). O. Andreassen is supported by the Research Council of Norway (grant 223273), Norwegian Health Association, and the KG Jebsen Stiftelsen. L. Benussi, R. Ghidoni, G. Rossi, and F. Tagliavini are supported by the Italian Ministry of Health-Ricerca Corrente. G. Bråthen and R. Ghidoni are supported by the Italian Ministry of Health (grant RF-2016-02361492). D. Blackburn is supported by the Sheffield Biomedical Research Centre. L. Bernardi is supported by the National Institute for Health Research Cambridge Biomedical Research Centre and Biomedical Research Unit in Dementia (NIHR, grant RG64473). T.E. Cope is supported by the Association of British Neurologists; the recruitment and clinical characterization of research participants at Washington University were supported by $\mathrm{NIH}$ (grants R01AG044546, RF1AG053303, R01AG058501, U01AG058922, P50 AG05681, P01 AG03991, and P01 AG026276). F. Frangipane is supported by ONLUS Lamezia Terme. C. Graff is supported by grants from JPND Prefrontals Swedish Research Council (VR) 529-2014-7504, Swedish Research Council (VR) 2015-02926, Swedish Research Council (VR) 2018-02754, Swedish FTD Initiative-Schörling Foundation, Swedish Brain Foundation, Swedish Alzheimer Foundation, Stockholm County Council ALF, Karolinska Institutet Doctoral Funding, and StratNeuro, Swedish Demensfonden. M. Gallo is supported by the NIH (grant AG054519). M. Gallucci, E. Scarpini, J.C. Thompson and V.M. Van Deerlin are supported by the NIH (grant AG017586, and P30 AG10124 and U01 AG062418). J. Hardy and P.A. Lewis are supported by an MRC Programme grant (MR/N026004/1). J. Hardy is supported by the UK Dementia Research Institute, which receives its funding from DRI Ltd, funded by the UK Medical Research Council, Alzheimer's Society and Alzheimer's Research UK, Wellcome Trust (award 202903/Z/16/Z), Dolby Family Fund, National Institute for Health Research University College London Hospitals Biomedical Research Centre, BRCNIHR Biomedical Research Centre at University College London Hospitals NHS Foundation Trust, and University College London. R. Maletta is supported by the Associazione per la
Ricerca Neurogenetica. B. Miller is supported by the NIH (grants P50-AG023501 and P01-AG1972403) (BLM). C.M. Morris is supported by the Newcastle Brain Tissue Resource, the UK Medical Research Council (grant G0400074), the NIHR Newcastle Biomedical Research Centre awarded to the Newcastle upon Tyne NHS Foundation Trust and Newcastle University, and a grant from the Alzheimer's Society and Alzheimer's Research UK as part of the Brains for Dementia Research Project. B. Nacmias and S.B. Sando are supported by the Ricerca di Ateneo 2019. E. Rogaeva is supported by the Canadian Consortium on Neurodegeneration in Aging. B. Rogelj is supported by grants from the Slovenian Research Agency (grants P4-0127, J3-8201, J3-9263). J. van Rooij is supported by the Wellcome Trust (grant 103838), by the Medical Research Council (grant number SUAG004/91365), and by the National Institute for Health Research Cambridge Biomedical Research Centre and Biomedical Research Unit in Dementia (NIHR, grant RG64473). A. Rendina is supported by the Innovative Medicines Initiative 2 Joint Undertaking, which receives support from the European Union's Horizon 2020 research and innovation programme and EFPIA (grant 115975), by Acción Estratégica en Salud integrated in the Spanish National R + D + I Plan (grants PI13/02434 and PI16/01861), by ISCIII (Instituto de Salud Carlos III) Subdirección General de Evaluación, and by the Fondo Europeo de Desarrollo Regional (FEDER-Una manera de Hacer Europa). M. Boada and A. Ruiz are funded by Fundación bancaria La Caixa and Grifols SA (GR@ACE project). R. Sanchez-Valle is funded by the Spanish National Institute of Health Carlos III (ISCIII) under the aegis of the EU Joint Programme-Neurodegenerative Disease Research (JPND) (grant AC14/00013) and Fundacio Marato de TV3 (20143810) (RSV). J.Q. Trojanowski is supported by the NIH (grant AG09215). C. Van Broeckhoven and J. Van der Zee are supported by the Flemish Government initiated Impulse Program on Networks for Dementia Research (VIND) and the Methusalem Excellence Program, by the Research Foundation Flanders (FWO), and by the University of Antwerp Research Fund (Belgium). M.L. Waldö is supported by the Elly Berggren Foundation. J. Yokoyama is funded by NIA K01 AG049152.

\section{Disclosure}

C. Cruchaga receives research support from Biogen, EISAI, Alector, and Parabon. The funders of the study had no role in the collection, analysis, or interpretation of data, in the writing of the report, or in the decision to submit the paper for publication. C. Cupidi is a member of the advisory board of ADx Healthcare and Vivid Genomics. B. Costa, C. Manzoni, M. Bernal-Quiros, D.A. Kia, M. Aguilar, I. Alvarez, V. Alvarez, O. Andreassen, M. Anfossi, S. Bagnoli, L. Benussi, L. Bernardi, G. Binetti, D. Blackburn, M. Boada, B. Borroni, L. Bowns, G. Bråthen, A.C. Bruni, H.-H. Chiang, J. Clarimon, S. Colville, M.E. Conidi, T.E. Cope, C. Cruchaga, M.E. Di Battista, J. Diehl-Schmid, M. Diez-Fairen, O. Dols-Icardo, E. Durante, D. Flisar, F. Frangipane, D. Galimberti, M. Gallo, M. Gallucci, R. 
Ghidoni, C. Graff, J.H. Grafman, M. Grossman, J. Hardy, I. Hernández, G.J.T. Holloway, E.D. Huey, I. Illán-Gala, A. Karydas, B. Khoshnood, M.G. Kramberger, M. Kristiansen, P.A. Lewis, A. Lleó, G.K. Madhan, R. Maletta, A. Maver, M. Menendez-Gonzalez, G. Milan, B. Miller, M.O. Mol, P. Momeni, S. Moreno-Grau, C.M. Morris, B. Nacmias, C. Nilsson, V. Novelli, L. Öijerstedt, A. Padovani, S. Pal, Y. Panchbhaya, P. Pastor, B. Peterlin, I. Piaceri, S. PickeringBrown, Y.A.L. Pijnenburg, A.A. Puca, I. Rainero, A. Rendina, A.M.T. Richardson, E. Rogaeva, B. Rogelj, S. Rollinson, G. Rossi, C. Rossmeier, J.B. Rowe, E. Rubino, A. Ruiz, R. Sanchez-Valle, S.B. Sando, A.F. Santillo, J. Saxon, E. Scarpini, M. Serpente, N. Smirne, S. Sorbi, E. Suh, F. Tagliavini, J.C. Thompson, J.Q. Trojanowski, V.M. Van Deerlin, J. Van der Zee, C. Van Broeckhoven, J. van Rooij, J.C. Van Swieten, A. Veronesi, E. Vitale, M.L. Waldö, C. Woodward, J. Yokoyama, V. Escott-Price, J.M. Polke, and R. Ferrari report no disclosures relevant to the manuscript. Go to Neurology.org/N for full disclosures.

\section{Publication history}

Received by Neurology April 15, 2020. Accepted in final form August 12, 2020.

Appendix 1 Authors

\begin{tabular}{|c|c|c|}
\hline Name & Location & Contribution \\
\hline $\begin{array}{l}\text { Beatrice } \\
\text { Costa, BSc }\end{array}$ & $\begin{array}{l}\text { University College } \\
\text { London, Institute of } \\
\text { Neurology, UK }\end{array}$ & $\begin{array}{l}\text { C9orf72 expansions } \\
\text { screening, data } \\
\text { interpretation and } \\
\text { drafting of manuscript }\end{array}$ \\
\hline $\begin{array}{l}\text { Claudia } \\
\text { Manzoni, PhD }\end{array}$ & $\begin{array}{l}\text { School of Pharmacy, } \\
\text { University College } \\
\text { London, UK }\end{array}$ & $\begin{array}{l}\text { Project design, data } \\
\text { analyses and } \\
\text { interpretation, } \\
\text { manuscript drafting }\end{array}$ \\
\hline $\begin{array}{l}\text { Manuel } \\
\text { Bernal- } \\
\text { Quiros, PhD }\end{array}$ & $\begin{array}{l}\text { Neurogenetics } \\
\text { Laboratory, National } \\
\text { Hospital for Neurology } \\
\text { and Neurosurgery, } \\
\text { London, UK }\end{array}$ & $\begin{array}{l}\text { C9orf72 expansions } \\
\text { screening, data } \\
\text { interpretation and } \\
\text { drafting of manuscript }\end{array}$ \\
\hline $\begin{array}{l}\text { Demis A. Kia, } \\
\text { MD }\end{array}$ & $\begin{array}{l}\text { University College } \\
\text { London, Institute of } \\
\text { Neurology, UK }\end{array}$ & $\begin{array}{l}\text { Data interpretation and } \\
\text { drafting of manuscript }\end{array}$ \\
\hline $\begin{array}{l}\text { Miquel } \\
\text { Aguilar, MD }\end{array}$ & $\begin{array}{l}\text { Aptima Clinic, Terrassa, } \\
\text { Barcelona, Spain }\end{array}$ & $\begin{array}{l}\text { Critical review of manuscript } \\
\text { for intellectual content, } \\
\text { contribution of samples and } \\
\text { demographics metadata }\end{array}$ \\
\hline $\begin{array}{l}\text { Ignacio } \\
\text { Alvarez, MSc }\end{array}$ & $\begin{array}{l}\text { Memory Disorders Unit, } \\
\text { Department of Neurology, } \\
\text { University Hospital Mutua de } \\
\text { Terrassa, Barcelona, Spain }\end{array}$ & $\begin{array}{l}\text { Critical review of manuscript } \\
\text { for intellectual content, } \\
\text { contribution of samples and } \\
\text { demographics metadata }\end{array}$ \\
\hline $\begin{array}{l}\text { Victoria } \\
\text { Alvarez, PhD }\end{array}$ & $\begin{array}{l}\text { Hospital Universitario } \\
\text { Central de Asturias, } \\
\text { Oviedo, Asturias, Spain }\end{array}$ & $\begin{array}{l}\text { Critical review of manuscript } \\
\text { for intellectual content, } \\
\text { contribution of samples and } \\
\text { demographics metadata }\end{array}$ \\
\hline $\begin{array}{l}\text { Ole A. } \\
\text { Andreassen, } \\
\text { MD, PhD }\end{array}$ & $\begin{array}{l}\text { NORMENT, Institute of } \\
\text { Clinical Medicine, } \\
\text { University of Oslo, } \\
\text { Norway }\end{array}$ & $\begin{array}{l}\text { Critical review of } \\
\text { manuscript for } \\
\text { intellectual content, } \\
\text { contribution of samples } \\
\text { and demographics } \\
\text { metadata }\end{array}$ \\
\hline
\end{tabular}

Appendix 1 (continued)

\begin{tabular}{lll}
\hline Name & Location & Contribution \\
\hline $\begin{array}{l}\text { Maria Anfossi, } \\
\text { PhD }\end{array}$ & $\begin{array}{l}\text { Regional Neurogenetic } \\
\text { Centre, ASPCZ, Lamezia } \\
\text { Terme, Italy }\end{array}$ & $\begin{array}{l}\text { Critical review of manuscript } \\
\text { for intellectual content, } \\
\text { contribution of samples and } \\
\text { demographics metadata }\end{array}$ \\
\hline $\begin{array}{l}\text { Silvia Bagnoli, } \\
\text { PhD }\end{array}$ & $\begin{array}{l}\text { Department of } \\
\text { Neuroscience, } \\
\text { Psychology, Drug } \\
\text { Research and Child } \\
\text { Health, University of } \\
\text { Florence, Italy }\end{array}$ & $\begin{array}{l}\text { Critical review of } \\
\text { manuscript for } \\
\text { intellectual content, } \\
\text { contribution of samples } \\
\text { and demographics } \\
\text { metadata }\end{array}$ \\
\hline
\end{tabular}

Luisa Benussi, Molecular Markers

PhD Laboratory, IRCCS Istituto

Centro San Giovanni di

Critical review of

manuscript for

intellectual content contribution of samples and demographics metadata

\begin{tabular}{ll}
\hline Livia & Regional Neurogenetic \\
Bernardi, PhD & Centre, ASPCZ, Lamezia \\
& Terme, Italy
\end{tabular}

Critical review of manuscript for intellectual content contribution of samples and demographics metadata

\begin{tabular}{lll}
\hline Giuliano & Molecular Markers & Critical review of \\
Binetti, MD & Laboratory, IRCCS Istituto & manuscript for \\
& Centro San Giovanni di & intellectual content, \\
& Dio Fatebenefratelli, & contribution of samples \\
Brescia, Italy & $\begin{array}{l}\text { and demographics } \\
\text { metadata }\end{array}$
\end{tabular}

\begin{tabular}{|c|c|c|}
\hline $\begin{array}{l}\text { Daniel J. } \\
\text { Blackburn, } \\
\text { MD, PhD }\end{array}$ & $\begin{array}{l}\text { Sheffield Institute for } \\
\text { Translational } \\
\text { Neuroscience (SITraN), } \\
\text { Department of } \\
\text { Neuroscience, University } \\
\text { of Sheffield, } \\
\text { UK }\end{array}$ & $\begin{array}{l}\text { Critical review of } \\
\text { manuscript for } \\
\text { intellectual content, } \\
\text { contribution of samples } \\
\text { and demographics } \\
\text { metadata }\end{array}$ \\
\hline $\begin{array}{l}\text { Mercè Boada, } \\
\text { MD, PhD }\end{array}$ & $\begin{array}{l}\text { Research Center and } \\
\text { Memory Clinic, Fundació } \\
\text { ACE, Institut Català de } \\
\text { Neurociències Aplicades, } \\
\text { Universitat Internacional } \\
\text { de Catalunya (UIC), } \\
\text { Barcelona, Spain }\end{array}$ & $\begin{array}{l}\text { Critical review of } \\
\text { manuscript for } \\
\text { intellectual content, } \\
\text { contribution of samples } \\
\text { and demographics } \\
\text { metadata }\end{array}$ \\
\hline $\begin{array}{l}\text { Barbara } \\
\text { Borroni, MD }\end{array}$ & $\begin{array}{l}\text { Centre for } \\
\text { Neurodegenerative } \\
\text { Disorders, Department of } \\
\text { Clinical and Experimental } \\
\text { Sciences, University of } \\
\text { Brescia, Italy }\end{array}$ & $\begin{array}{l}\text { Critical review of } \\
\text { manuscript for } \\
\text { intellectual content, } \\
\text { contribution of samples } \\
\text { and demographics } \\
\text { metadata }\end{array}$ \\
\hline Lucy Bowns & $\begin{array}{l}\text { Department of Clinical } \\
\text { Neurosciences, } \\
\text { Cambridge University, UK }\end{array}$ & $\begin{array}{l}\text { Critical review of } \\
\text { manuscript for } \\
\text { intellectual content, } \\
\text { contribution of samples } \\
\text { and demographics } \\
\text { metadata }\end{array}$ \\
\hline $\begin{array}{l}\text { Geir Bråthen, } \\
\text { MD, PhD }\end{array}$ & $\begin{array}{l}\text { Department of } \\
\text { Neurology, University } \\
\text { Hospital of Trondheim, } \\
\text { Norway }\end{array}$ & $\begin{array}{l}\text { Critical review of } \\
\text { manuscript for } \\
\text { intellectual content, } \\
\text { contribution of samples } \\
\text { and demographics } \\
\text { metadata }\end{array}$ \\
\hline $\begin{array}{l}\text { Amalia C. } \\
\text { Bruni, MD }\end{array}$ & $\begin{array}{l}\text { Regional Neurogenetic } \\
\text { Centre, ASPCZ, Lamezia } \\
\text { Terme, Italy }\end{array}$ & $\begin{array}{l}\text { Critical review of } \\
\text { manuscript for } \\
\text { intellectual content, } \\
\text { contribution of samples } \\
\text { and demographics } \\
\text { metadata }\end{array}$ \\
\hline
\end{tabular}


Appendix 1 (continued)

\begin{tabular}{lll}
\hline Name & Location & Contribution \\
\hline Huei-Hsin & Karolinska Institutet, Dept & Critical review of \\
Chiang, PhD & NVS, Division of & manuscript for \\
& Neurogeriatrics, & intellectual content, \\
& Bioclinicum, Solna, & contribution of samples \\
& Sweden & $\begin{array}{l}\text { and demographics } \\
\text { metadata }\end{array}$
\end{tabular}

\begin{tabular}{lll}
\hline $\begin{array}{l}\text { Jordi } \\
\text { Clarimon, PhD }\end{array}$ & $\begin{array}{l}\text { Department of } \\
\text { Neurology, IIB Sant Pau, } \\
\text { Hospital de la Santa Creu i } \\
\text { Sant Pau, Universitat } \\
\text { Autònoma de Barcelona, } \\
\text { Spain }\end{array}$ & $\begin{array}{l}\text { Critical review of } \\
\text { manuscript for } \\
\text { intellectual content, } \\
\text { contribution of samples } \\
\text { and demographics } \\
\text { metadata }\end{array}$ \\
\hline $\begin{array}{l}\text { Shuna } \\
\text { Colville, MSc }\end{array}$ & $\begin{array}{ll}\text { Anne Rowling } \\
\text { Regenerative Neurology } \\
\text { Clinic, University of } \\
\text { Edinburgh, UK }\end{array}$ & $\begin{array}{l}\text { Critical review of } \\
\text { manuscript for } \\
\text { intellectual content, } \\
\text { contribution of samples } \\
\text { and demographics } \\
\text { metadata }\end{array}$ \\
& &
\end{tabular}

\begin{tabular}{lll}
\hline Maria E. & Regional Neurogenetic & Critical review of \\
Conidi, PhD & Centre, ASPCZ, Lamezia & manuscript for \\
& Terme, Italy & intellectual content, \\
& & contribution of samples \\
& & and demographics \\
& metadata
\end{tabular}

\begin{tabular}{lll}
\hline Tom E. Cope, & Department of Clinical & Critical review of \\
MD, PhD & Neurosciences, & manuscript for \\
& Cambridge University, UK & intellectual content, \\
& & contribution of samples \\
& and demographics \\
& metadata
\end{tabular}

\begin{tabular}{lll}
\hline $\begin{array}{l}\text { Carlos } \\
\text { Cruchaga, } \\
\text { PhD }\end{array}$ & $\begin{array}{l}\text { NeuroGenomics and } \\
\text { Informatics, Washington } \\
\text { University, Department of } \\
\text { Psychiatry, St. Louis, MO }\end{array}$ & $\begin{array}{l}\text { Critical review of } \\
\text { manuscript for } \\
\text { intellectual content }\end{array}$ \\
\hline $\begin{array}{l}\text { Chiara Cupidi, } \\
\text { MD }\end{array}$ & $\begin{array}{ll}\text { Regional Neurogenetic } \\
\text { Centre, ASPCZ, Lamezia } \\
\text { Terme, Italy }\end{array}$ & $\begin{array}{l}\text { Critical review of } \\
\text { manuscript for } \\
\text { intellectual content, } \\
\text { contribution of samples } \\
\text { and demographics } \\
\text { metadata }\end{array}$ \\
& & \\
& &
\end{tabular}

\begin{tabular}{lll}
\hline Maria Elena Di & Cognitive Impairment & Critical review of \\
Battista, MD, & Center, Local Health & manuscript for \\
PhD & Authority n.2 Marca & intellectual content, \\
& Trevigiana, Treviso, Italy & $\begin{array}{l}\text { contribution of samples } \\
\text { and demographics } \\
\end{array}$ \\
& & metadata
\end{tabular}

\begin{tabular}{|c|c|c|}
\hline $\begin{array}{l}\text { Janine Diehl- } \\
\text { Schmid, MD }\end{array}$ & $\begin{array}{l}\text { Technical University of } \\
\text { Munich, School of } \\
\text { Medicine, Department of } \\
\text { Psychiatry and } \\
\text { Psychotherapy, Germany }\end{array}$ & $\begin{array}{l}\text { Critical review of } \\
\text { manuscript for } \\
\text { intellectual content, } \\
\text { contribution of samples } \\
\text { and demographics } \\
\text { metadata }\end{array}$ \\
\hline $\begin{array}{l}\text { Monica Diez- } \\
\text { Fairen, MSc }\end{array}$ & $\begin{array}{l}\text { Memory Disorders Unit, } \\
\text { Department of } \\
\text { Neurology, University } \\
\text { Hospital Mutua de } \\
\text { Terrassa, Barcelona, } \\
\text { Spain }\end{array}$ & $\begin{array}{l}\text { Critical review of } \\
\text { manuscript for } \\
\text { intellectual content, } \\
\text { contribution of samples } \\
\text { and demographics } \\
\text { metadata }\end{array}$ \\
\hline $\begin{array}{l}\text { Oriol Dols- } \\
\text { Icardo, PhD }\end{array}$ & $\begin{array}{l}\text { Department of } \\
\text { Neurology, IIB Sant Pau, } \\
\text { Hospital de la Santa Creu i } \\
\text { Sant Pau, Universitat } \\
\text { Autònoma de Barcelona, } \\
\text { Barcelona, } \\
\text { Spain }\end{array}$ & $\begin{array}{l}\text { Critical review of } \\
\text { manuscript for } \\
\text { intellectual content, } \\
\text { contribution of samples } \\
\text { and demographics } \\
\text { metadata }\end{array}$ \\
\hline
\end{tabular}

Appendix 1 (continued)

\begin{tabular}{|c|c|c|}
\hline Name & Location & Contribution \\
\hline $\begin{array}{l}\text { Elisabetta } \\
\text { Durante, PhD }\end{array}$ & $\begin{array}{l}\text { Immunohematology and } \\
\text { Transfusional Medicine } \\
\text { Service, Local Health } \\
\text { Authority n.2 Marca } \\
\text { Trevigiana, Treviso, Italy }\end{array}$ & $\begin{array}{l}\text { Critical review of } \\
\text { manuscript for } \\
\text { intellectual content, } \\
\text { contribution of samples } \\
\text { and demographics } \\
\text { metadata }\end{array}$ \\
\hline
\end{tabular}

\begin{tabular}{|c|c|c|}
\hline $\begin{array}{l}\text { Dušan Flisar, } \\
\text { MD }\end{array}$ & $\begin{array}{l}\text { Department of } \\
\text { Neurology, University } \\
\text { Medical Center Ljubljana, } \\
\text { Slovenia }\end{array}$ & $\begin{array}{l}\text { Critical review of manuscript } \\
\text { for intellectual content, } \\
\text { contribution of samples and } \\
\text { demographics metadata }\end{array}$ \\
\hline $\begin{array}{l}\text { Francesca } \\
\text { Frangipane, } \\
\text { MD }\end{array}$ & $\begin{array}{l}\text { Regional Neurogenetic } \\
\text { Centre, ASPCZ, Lamezia } \\
\text { Terme, Italy }\end{array}$ & $\begin{array}{l}\text { Critical review of manuscript } \\
\text { for intellectual content, } \\
\text { contribution of samples and } \\
\text { demographics metadata }\end{array}$ \\
\hline $\begin{array}{l}\text { Daniela } \\
\text { Galimberti, } \\
\text { PhD }\end{array}$ & $\begin{array}{l}\text { University of Milan, Dino } \\
\text { Ferrari Center, Italy }\end{array}$ & $\begin{array}{l}\text { Critical review of manuscript } \\
\text { for intellectual content, } \\
\text { contribution of samples and } \\
\text { demographics metadata }\end{array}$ \\
\hline $\begin{array}{l}\text { Maura Gallo, } \\
\text { PhD }\end{array}$ & $\begin{array}{l}\text { Regional Neurogenetic } \\
\text { Centre, ASPCZ, Lamezia } \\
\text { Terme, Italy }\end{array}$ & $\begin{array}{l}\text { Critical review of } \\
\text { manuscript for intellectual } \\
\text { content, contribution of } \\
\text { samples and } \\
\text { demographics metadata }\end{array}$ \\
\hline $\begin{array}{l}\text { Maurizio } \\
\text { Gallucci, MD }\end{array}$ & $\begin{array}{l}\text { Cognitive Impairment } \\
\text { Center, Local Health } \\
\text { Authority n.2 Marca } \\
\text { Trevigiana, Treviso, Italy }\end{array}$ & $\begin{array}{l}\text { Critical review of } \\
\text { manuscript for } \\
\text { intellectual content, } \\
\text { contribution of samples } \\
\text { and demographics } \\
\text { metadata }\end{array}$ \\
\hline
\end{tabular}

\begin{tabular}{lll}
\hline Roberta & Molecular Markers & Critical review of \\
Ghidoni, PhD & Laboratory, IRCCS Istituto & manuscript for \\
& Centro San Giovanni di & intellectual conten
\end{tabular}

Centro San Giovanni di intellectual content, Dio Fatebenefratelli, contribution of samples Brescia, Italy and demographics metadata

\begin{tabular}{ll}
\hline Caroline & Karolinska Institutet, Dept \\
Graff, MD, & NVS, Division of \\
PhD & Neurogeriatrics, \\
& Bioclinicum, Solna, \\
& Sweden
\end{tabular}

\section{Critical review of} manuscript for intellectual content contribution of samples and demographics metadata

\begin{tabular}{ll}
\hline Jordan H. & Cognitive Neuroscience \\
Grafman, PhD & Lab, Think and Speak Lab, \\
& Shirley Ryan AbilityLab, \\
& Chicago, IL
\end{tabular}

Critical review of manuscript for intellectual content, contribution of samples and demographics metadata

\begin{tabular}{|c|c|c|}
\hline $\begin{array}{l}\text { Murray } \\
\text { Grossman, } \\
\text { MD }\end{array}$ & $\begin{array}{l}\text { Department of } \\
\text { Neurology, Perelman } \\
\text { School of Medicine at the } \\
\text { University of } \\
\text { Pennsylvania, } \\
\text { Philadelphia }\end{array}$ & $\begin{array}{l}\text { Critical review of } \\
\text { manuscript for } \\
\text { intellectual content, } \\
\text { contribution of samples } \\
\text { and demographics } \\
\text { metadata }\end{array}$ \\
\hline $\begin{array}{l}\text { John Hardy, } \\
\text { PhD }\end{array}$ & $\begin{array}{l}\text { UCL Dementia Research } \\
\text { Institute Wing } 1.2 \\
\text { Cruciform Building, } \\
\text { London, UK }\end{array}$ & $\begin{array}{l}\text { Critical review of } \\
\text { manuscript for } \\
\text { intellectual content }\end{array}$ \\
\hline $\begin{array}{l}\text { Isabel } \\
\text { Hernández, } \\
\text { MD, PhD }\end{array}$ & $\begin{array}{l}\text { Research Center and } \\
\text { Memory Clinic. Fundació } \\
\text { ACE, Institut Català de } \\
\text { Neurociències Aplicades, } \\
\text { Universitat Internacional } \\
\text { de Catalunya (UIC), } \\
\text { Barcelona, Spain }\end{array}$ & $\begin{array}{l}\text { Critical review of } \\
\text { manuscript for } \\
\text { intellectual content, } \\
\text { contribution of samples } \\
\text { and demographics } \\
\text { metadata }\end{array}$ \\
\hline
\end{tabular}


Appendix 1 (continued)

\begin{tabular}{|c|c|c|}
\hline Name & Location & Contribution \\
\hline $\begin{array}{l}\text { Guy J.T. } \\
\text { Holloway, } \\
\text { MBBS, } \\
\text { MRCPsych }\end{array}$ & $\begin{array}{l}\text { Royal Edinburgh Hospital, } \\
\text { Edinburgh, UK }\end{array}$ & $\begin{array}{l}\text { Critical review of manuscript } \\
\text { for intellectual content, } \\
\text { contribution of samples and } \\
\text { demographics metadata }\end{array}$ \\
\hline $\begin{array}{l}\text { Edward D. } \\
\text { Huey, MD }\end{array}$ & $\begin{array}{l}\text { Taub Institute for } \\
\text { Research on Alzheimer's } \\
\text { Disease and the Aging } \\
\text { Brain, Columbia } \\
\text { University, New York, NY }\end{array}$ & $\begin{array}{l}\text { Critical review of } \\
\text { manuscript for } \\
\text { intellectual content, } \\
\text { contribution of samples } \\
\text { and demographics } \\
\text { metadata }\end{array}$ \\
\hline $\begin{array}{l}\text { Ignacio Illán- } \\
\text { Gala, MD, PhD }\end{array}$ & $\begin{array}{l}\text { Department of } \\
\text { Neurology, IIB Sant Pau, } \\
\text { Hospital de la Santa Creu i } \\
\text { Sant Pau, Universitat } \\
\text { Autònoma de Barcelona, } \\
\text { Spain }\end{array}$ & $\begin{array}{l}\text { Critical review of } \\
\text { manuscript for } \\
\text { intellectual content, } \\
\text { contribution of samples } \\
\text { and demographics } \\
\text { metadata }\end{array}$ \\
\hline $\begin{array}{l}\text { Anna Karydas, } \\
\text { MSc }\end{array}$ & $\begin{array}{l}\text { Department of } \\
\text { Neurology, Memory and } \\
\text { Aging Center, University } \\
\text { of California, San } \\
\text { Francisco }\end{array}$ & $\begin{array}{l}\text { Critical review of } \\
\text { manuscript for } \\
\text { intellectual content, } \\
\text { contribution of samples } \\
\text { and demographics } \\
\text { metadata }\end{array}$ \\
\hline $\begin{array}{l}\text { Behzad } \\
\text { Khoshnood, } \\
\text { PhD }\end{array}$ & $\begin{array}{l}\text { Karolinska Institutet, Dept } \\
\text { NVS, Division of } \\
\text { Neurogeriatrics, } \\
\text { Bioclinicum, Solna, } \\
\text { Sweden }\end{array}$ & $\begin{array}{l}\text { Critical review of } \\
\text { manuscript for } \\
\text { intellectual content, } \\
\text { contribution of samples } \\
\text { and demographics } \\
\text { metadata }\end{array}$ \\
\hline $\begin{array}{l}\text { Milica G. } \\
\text { Kramberger, } \\
\text { MD, PhD }\end{array}$ & $\begin{array}{l}\text { Department of } \\
\text { Neurology, University } \\
\text { Medical Center Ljubljana, } \\
\text { Slovenia }\end{array}$ & $\begin{array}{l}\text { Critical review of } \\
\text { manuscript for } \\
\text { intellectual content, } \\
\text { contribution of samples } \\
\text { and demographics } \\
\text { metadata }\end{array}$ \\
\hline $\begin{array}{l}\text { Mark } \\
\text { Kristiansen, } \\
\text { PhD }\end{array}$ & $\begin{array}{l}\text { UCL Genomics, UCL Great } \\
\text { Ormond Street Institute of } \\
\text { Child Health, London, UK }\end{array}$ & $\begin{array}{l}\text { Critical review of } \\
\text { manuscript for } \\
\text { intellectual content }\end{array}$ \\
\hline $\begin{array}{l}\text { Patrick A. } \\
\text { Lewis, PhD }\end{array}$ & $\begin{array}{l}\text { The Royal Veterinary } \\
\text { College, Department of } \\
\text { Comparative Biomedical } \\
\text { Sciences, London, UK }\end{array}$ & $\begin{array}{l}\text { Critical review of } \\
\text { manuscript for } \\
\text { intellectual content }\end{array}$ \\
\hline $\begin{array}{l}\text { Alberto Lleó, } \\
\text { MD, PhD }\end{array}$ & $\begin{array}{l}\text { Department of } \\
\text { Neurology, IIB Sant Pau, } \\
\text { Hospital de la Santa Creu i } \\
\text { Sant Pau, Universitat } \\
\text { Autònoma de Barcelona, } \\
\text { Spain }\end{array}$ & $\begin{array}{l}\text { Critical review of } \\
\text { manuscript for } \\
\text { intellectual content, } \\
\text { contribution of samples } \\
\text { and demographics } \\
\text { metadata }\end{array}$ \\
\hline $\begin{array}{l}\text { Gaganjit K. } \\
\text { Madhan, MSc }\end{array}$ & $\begin{array}{l}\text { UCL Genomics, UCL Great } \\
\text { Ormond Street Institute of } \\
\text { Child Health, London, UK }\end{array}$ & $\begin{array}{l}\text { Critical review of } \\
\text { manuscript for } \\
\text { intellectual content, } \\
\text { contribution of samples } \\
\text { and demographics } \\
\text { metadata }\end{array}$ \\
\hline $\begin{array}{l}\text { Raffaele } \\
\text { Maletta, MD }\end{array}$ & $\begin{array}{l}\text { Regional Neurogenetic } \\
\text { Centre, ASPCZ, Lamezia } \\
\text { Terme, Italy }\end{array}$ & $\begin{array}{l}\text { Critical review of } \\
\text { manuscript for } \\
\text { intellectual content, } \\
\text { contribution of samples } \\
\text { and demographics } \\
\text { metadata }\end{array}$ \\
\hline $\begin{array}{l}\text { Aleš Maver, } \\
\text { MD, PhD }\end{array}$ & $\begin{array}{l}\text { Clinical Institute of } \\
\text { Medical Genetics, } \\
\text { University Medical Center } \\
\text { Ljubljana, Slovenia }\end{array}$ & $\begin{array}{l}\text { Critical review of } \\
\text { manuscript for } \\
\text { intellectual content, } \\
\text { contribution of samples } \\
\text { and demographics } \\
\text { metadata }\end{array}$ \\
\hline
\end{tabular}

Appendix 1 (continued)

\begin{tabular}{|c|c|c|}
\hline Name & Location & Contribution \\
\hline $\begin{array}{l}\text { Manuel } \\
\text { Menendez- } \\
\text { Gonzalez, MD, } \\
\text { PhD }\end{array}$ & $\begin{array}{l}\text { Hospital Universitario } \\
\text { Central de Asturias, } \\
\text { Oviedo, Asturias, Spain }\end{array}$ & $\begin{array}{l}\text { Critical review of } \\
\text { manuscript for } \\
\text { intellectual content, } \\
\text { contribution of samples } \\
\text { and demographics } \\
\text { metadata }\end{array}$ \\
\hline
\end{tabular}

\begin{tabular}{ll}
\hline Graziella & Geriatric Center Frullone \\
Milan, MD & ASL Napoli 1 Centro, \\
& Napoli, Italy
\end{tabular}

Critical review of manuscript for intellectual content contribution of samples and demographics metadata

\begin{tabular}{ll}
\hline Bruce L. & Department of \\
Miller, MD & Neurology, Memory and \\
& Aging Center, University \\
& of California, San \\
& Francisco
\end{tabular}

Critical review of manuscript for intellectual content, contribution of samples and demographics metadata

\begin{tabular}{lll}
\hline Merel O. Mol, & $\begin{array}{l}\text { Department of } \\
\text { MSc }\end{array}$ & $\begin{array}{l}\text { Critical review of } \\
\text { manuscript for }\end{array}$ \\
& Medical Center, & intellectual content, \\
Rotterdam, the & contribution of samples \\
Netherlands & and demographics \\
& metadata
\end{tabular}

\begin{tabular}{lll}
\hline Parastoo & Rona Holdings, Silicon & $\begin{array}{l}\text { Critical review of } \\
\text { manuscript for } \\
\text { intellectual content, } \\
\text { contribution of metadata }\end{array}$ \\
& Valley, CA &
\end{tabular}

\section{Sonia Moreno- Research Center and Critical review of}

Grau, PhD Memory Clinic, Fundació manuscript for $\mathrm{ACE}$, Institut Català de intellectual content, Neurociències Aplicades, contribution of samples Universitat Internacional and demographics de Catalunya (UIC), metadata Barcelona, Spain

\begin{tabular}{lll}
\hline Christopher & Newcastle Brain Tissue & Critical review of \\
M. Morris, & Resource, Institute of & manuscript for \\
PhD & Neuroscience, Newcastle & intellectual content, \\
& University, Edwardson & contribution of samples \\
& Building, Campus for & and demographics \\
& Ageing and Vitality, & metadata
\end{tabular}

\begin{tabular}{lll}
\hline Benedetta & Department of & Critical review of \\
Nacmias, PhD & Neuroscience, & manuscript for \\
& Psychology, Drug & intellectual content, \\
& Research and Child & contribution of samples \\
& Health, University of & and demographics \\
& Florence, Italy & metadata
\end{tabular}

\begin{tabular}{|c|c|c|}
\hline $\begin{array}{l}\text { Christer } \\
\text { Nilsson, MD }\end{array}$ & $\begin{array}{l}\text { Department of } \\
\text { Neurology, Skåne } \\
\text { University Hospital, } \\
\text { Malmö, Sweden }\end{array}$ & $\begin{array}{l}\text { Critical review of } \\
\text { manuscript for } \\
\text { intellectual content, } \\
\text { contribution of samples } \\
\text { and demographics } \\
\text { metadata }\end{array}$ \\
\hline $\begin{array}{l}\text { Valeria } \\
\text { Novelli, PhD }\end{array}$ & $\begin{array}{l}\text { Fondazione Policlinico } \\
\text { Universitario A. Gemelli } \\
\text { IRCCS, Rome, Italy }\end{array}$ & $\begin{array}{l}\text { Critical review of } \\
\text { manuscript for } \\
\text { intellectual content, } \\
\text { contribution of samples } \\
\text { and demographics } \\
\text { metadata }\end{array}$ \\
\hline $\begin{array}{l}\text { Linn } \\
\text { Öijerstedt, } \\
\text { MD }\end{array}$ & $\begin{array}{l}\text { Karolinska Institutet, Dept } \\
\text { NVS, Division of } \\
\text { Neurogeriatrics, } \\
\text { Bioclinicum, Solna, } \\
\text { Sweden }\end{array}$ & $\begin{array}{l}\text { Critical review of } \\
\text { manuscript for } \\
\text { intellectual content, } \\
\text { contribution of samples } \\
\text { and demographics } \\
\text { metadata }\end{array}$ \\
\hline
\end{tabular}


Appendix 1 (continued)

\begin{tabular}{|c|c|c|c|c|c|}
\hline Name & Location & Contribution & Name & Location & Contribution \\
\hline $\begin{array}{l}\text { Alessandro } \\
\text { Padovani, MD }\end{array}$ & $\begin{array}{l}\text { Centre for } \\
\text { Neurodegenerative } \\
\text { Disorders, Department of } \\
\text { Clinical and Experimental } \\
\text { Sciences, University of } \\
\text { Brescia, Italy }\end{array}$ & $\begin{array}{l}\text { Critical review of } \\
\text { manuscript for } \\
\text { intellectual content, } \\
\text { contribution of samples } \\
\text { and demographics } \\
\text { metadata }\end{array}$ & $\begin{array}{l}\text { Anna M.T. } \\
\text { Richardson, } \\
\text { FRCP }\end{array}$ & $\begin{array}{l}\text { Manchester Centre for } \\
\text { Clinical Neurosciences, } \\
\text { Salford Royal NHS Trust, } \\
\text { Manchester, UK }\end{array}$ & $\begin{array}{l}\text { Critical review of } \\
\text { manuscript for } \\
\text { intellectual content, } \\
\text { contribution of samples } \\
\text { and demographics } \\
\text { metadata }\end{array}$ \\
\hline $\begin{array}{l}\text { Suvankar Pal, } \\
\text { MBBS, MRCP, } \\
\text { MD }\end{array}$ & $\begin{array}{l}\text { Anne Rowling } \\
\text { Regenerative Neurology } \\
\text { Clinic, University of } \\
\text { Edinburgh, UK }\end{array}$ & $\begin{array}{l}\text { Critical review of } \\
\text { manuscript for } \\
\text { intellectual content, } \\
\text { contribution of samples } \\
\text { and demographics } \\
\text { metadata }\end{array}$ & $\begin{array}{l}\text { Ekaterina } \\
\text { Rogaeva, PhD }\end{array}$ & $\begin{array}{l}\text { Tanz Centre for } \\
\text { Research in } \\
\text { Neurodegenerative } \\
\text { Diseases, University } \\
\text { of Toronto, } \\
\text { Canada }\end{array}$ & $\begin{array}{l}\text { Critical review of } \\
\text { manuscript for } \\
\text { intellectual content }\end{array}$ \\
\hline $\begin{array}{l}\text { Yasmin } \\
\text { Panchbhaya, } \\
\text { MSc }\end{array}$ & $\begin{array}{l}\text { UCL Genomics, UCL Great } \\
\text { Ormond Street Institute of } \\
\text { Child Health, London, UK }\end{array}$ & $\begin{array}{l}\text { Critical review of } \\
\text { manuscript for } \\
\text { intellectual content }\end{array}$ & $\begin{array}{l}\text { Boris Rogelj, } \\
\text { PhD }\end{array}$ & $\begin{array}{l}\text { Department of } \\
\text { Biotechnology, Jožef } \\
\text { Stefan Institute, Ljubljana, } \\
\text { Slovenia }\end{array}$ & $\begin{array}{l}\text { Critical review of manuscript } \\
\text { for intellectual content, } \\
\text { contribution of samples and } \\
\text { demographics metadata }\end{array}$ \\
\hline $\begin{array}{l}\text { Pau Pastor, } \\
\text { MD, PhD }\end{array}$ & $\begin{array}{l}\text { Memory Disorders Unit, } \\
\text { Department of } \\
\text { Neurology, University } \\
\text { Hospital Mutua de } \\
\text { Terrassa, Barcelona, } \\
\text { Spain }\end{array}$ & $\begin{array}{l}\text { Critical review of } \\
\text { manuscript for } \\
\text { intellectual content, } \\
\text { contribution of samples } \\
\text { and demographics } \\
\text { metadata }\end{array}$ & $\begin{array}{l}\text { Sara } \\
\text { Rollinson, } \\
\text { PhD }\end{array}$ & $\begin{array}{l}\text { Division of Neuroscience } \\
\text { \& Experimental } \\
\text { Psychology, The } \\
\text { University of Manchester, } \\
\text { UK }\end{array}$ & $\begin{array}{l}\text { Critical review of } \\
\text { manuscript for } \\
\text { intellectual content, } \\
\text { contribution of samples } \\
\text { and demographics } \\
\text { metadata }\end{array}$ \\
\hline $\begin{array}{l}\text { Borut } \\
\text { Peterlin, MD, } \\
\text { PhD }\end{array}$ & $\begin{array}{l}\text { Clinical Institute of } \\
\text { Medical Genetics, } \\
\text { University Medical Center } \\
\text { Ljubljana, Slovenia }\end{array}$ & $\begin{array}{l}\text { Critical review of } \\
\text { manuscript for } \\
\text { intellectual content, } \\
\text { contribution of samples } \\
\text { and demographics } \\
\text { metadata }\end{array}$ & $\begin{array}{l}\text { Giacomina } \\
\text { Rossi, PhD }\end{array}$ & $\begin{array}{l}\text { Division of Neurology V } \\
\text { and Neuropathology; } \\
\text { Fondazione IRCCS Istituto } \\
\text { Neurologico Carlo Besta, } \\
\text { Milan, Italy }\end{array}$ & $\begin{array}{l}\text { Critical review of } \\
\text { manuscript for } \\
\text { intellectual content, } \\
\text { contribution of samples } \\
\text { and demographics } \\
\text { metadata }\end{array}$ \\
\hline $\begin{array}{l}\text { Irene Piaceri, } \\
\text { PhD }\end{array}$ & $\begin{array}{l}\text { Department of } \\
\text { Neuroscience, } \\
\text { Psychology, Drug } \\
\text { Research and Child } \\
\text { Health, University of } \\
\text { Florence, Italy }\end{array}$ & $\begin{array}{l}\text { Critical review of } \\
\text { manuscript for } \\
\text { intellectual content, } \\
\text { contribution of } \\
\text { samples and } \\
\text { demographics } \\
\text { metadata }\end{array}$ & $\begin{array}{l}\text { Carola } \\
\text { Roßmeier, MD }\end{array}$ & $\begin{array}{l}\text { Technical University of } \\
\text { Munich, School of } \\
\text { Medicine, Department of } \\
\text { Psychiatry and } \\
\text { Psychotherapy, Germany }\end{array}$ & $\begin{array}{l}\text { Critical review of } \\
\text { manuscript for } \\
\text { intellectual content, } \\
\text { contribution of samples } \\
\text { and demographics } \\
\text { metadata }\end{array}$ \\
\hline $\begin{array}{l}\text { Stuart } \\
\text { Pickering- } \\
\text { Brown, PhD }\end{array}$ & $\begin{array}{l}\text { Division of Neuroscience } \\
\text { \& Experimental } \\
\text { Psychology, The } \\
\text { University of Manchester, } \\
\text { UK }\end{array}$ & $\begin{array}{l}\text { Critical review of } \\
\text { manuscript for } \\
\text { intellectual content, } \\
\text { contribution of samples } \\
\text { and demographics } \\
\text { metadata }\end{array}$ & $\begin{array}{l}\text { James B. } \\
\text { Rowe, MD, } \\
\text { PhD }\end{array}$ & $\begin{array}{l}\text { Department of Clinical } \\
\text { Neurosciences, } \\
\text { Cambridge University, UK }\end{array}$ & $\begin{array}{l}\text { Critical review of } \\
\text { manuscript for } \\
\text { intellectual content, } \\
\text { contribution of samples } \\
\text { and demographics } \\
\text { metadata }\end{array}$ \\
\hline $\begin{array}{l}\text { Yolande A.L. } \\
\text { Pijnenburg, } \\
\text { MD, PhD }\end{array}$ & $\begin{array}{l}\text { Amsterdam University } \\
\text { Medical Center, VU } \\
\text { University Medical Center, } \\
\text { the Netherlands }\end{array}$ & $\begin{array}{l}\text { Critical review of } \\
\text { manuscript for } \\
\text { intellectual content, } \\
\text { contribution of } \\
\text { samples and } \\
\text { demographics } \\
\text { metadata }\end{array}$ & $\begin{array}{l}\text { Elisa Rubino, } \\
\text { MD, PhD }\end{array}$ & $\begin{array}{l}\text { Neurology I, Department } \\
\text { of Neuroscience, } \\
\text { University of Torino, Italy }\end{array}$ & $\begin{array}{l}\text { Critical review of } \\
\text { manuscript for } \\
\text { intellectual content, } \\
\text { contribution of samples } \\
\text { and demographics } \\
\text { metadata }\end{array}$ \\
\hline $\begin{array}{l}\text { Annibale A. } \\
\text { Puca, MD }\end{array}$ & $\begin{array}{l}\text { Cardiovascular Research } \\
\text { Unit, IRCCS Multimedica, } \\
\text { Milan, Italy }\end{array}$ & $\begin{array}{l}\text { Critical review of } \\
\text { manuscript for } \\
\text { intellectual content, } \\
\text { contribution of samples } \\
\text { and demographics } \\
\text { metadata }\end{array}$ & $\begin{array}{l}\text { Agustín Ruiz, } \\
\text { MD, PhD }\end{array}$ & $\begin{array}{l}\text { Research Center and } \\
\text { Memory Clinic. Fundació } \\
\text { ACE, Institut Català de } \\
\text { Neurociències Aplicades, } \\
\text { Universitat Internacional } \\
\text { de Catalunya (UIC), } \\
\text { Barcelona, Spain }\end{array}$ & $\begin{array}{l}\text { Critical review of } \\
\text { manuscript for } \\
\text { intellectual content, } \\
\text { contribution of samples } \\
\text { and demographics } \\
\text { metadata }\end{array}$ \\
\hline $\begin{array}{l}\text { Innocenzo } \\
\text { Rainero, MD, } \\
\text { PhD }\end{array}$ & $\begin{array}{l}\text { Neurology I, Department } \\
\text { of Neuroscience, } \\
\text { University of Torino, Italy }\end{array}$ & $\begin{array}{l}\text { Critical review of } \\
\text { manuscript for } \\
\text { intellectual content, } \\
\text { contribution of samples } \\
\text { and demographics } \\
\text { metadata }\end{array}$ & $\begin{array}{l}\text { Raquel } \\
\text { Sanchez-Valle, } \\
\text { MD, PhD }\end{array}$ & $\begin{array}{l}\text { Alzheimer's Disease and } \\
\text { Other Cognitive Disorders } \\
\text { Unit, Hospital Clínic of } \\
\text { Barcelona, Spain }\end{array}$ & $\begin{array}{l}\text { Critical review of } \\
\text { manuscript for } \\
\text { intellectual content, } \\
\text { contribution of samples } \\
\text { and demographics } \\
\text { metadata }\end{array}$ \\
\hline $\begin{array}{l}\text { Antonella } \\
\text { Rendina, PhD }\end{array}$ & $\begin{array}{l}\text { NeurOMICS laboratory, } \\
\text { Institute of Biochemistry } \\
\text { and Cell Biology (IBBC), } \\
\text { CNR Napoli, Italy }\end{array}$ & $\begin{array}{l}\text { Critical review of } \\
\text { manuscript for } \\
\text { intellectual content, } \\
\text { contribution of samples } \\
\text { and demographics } \\
\text { metadata }\end{array}$ & $\begin{array}{l}\text { Sigrid B. } \\
\text { Sando, PhD }\end{array}$ & $\begin{array}{l}\text { Department of } \\
\text { Neurology, University } \\
\text { Hospital of Trondheim, } \\
\text { Norway }\end{array}$ & $\begin{array}{l}\text { Critical review of } \\
\text { manuscript for } \\
\text { intellectual content, } \\
\text { contribution of samples } \\
\text { and demographics } \\
\text { metadata }\end{array}$ \\
\hline
\end{tabular}

Appendix 1 (continued)

James B. Department of Clinical Critical review of

manuscript for

intellectual content contribution of samples and demographics Critical review of manuscript for intellectual content, contribution of samples metadata 
Appendix 1 (continued)

\begin{tabular}{lll}
\hline Name & Location & Contribution \\
\hline Alexander F. & Clinical Memory Research & Critical review of \\
Santillo, MD, & Unit, Lund University, & manuscript for \\
PhD & Sweden & intellectual content, \\
& & contribution of samples \\
& and demographics \\
& metadata
\end{tabular}

\begin{tabular}{lll}
\hline Jennifer & Manchester Centre for & Critical review of \\
Saxon, MSc & Clinical Neurosciences, & manuscript for \\
& Salford Royal NHS Trust, & intellectual content, \\
& UK & contribution of samples \\
& & and demographics \\
& metadata
\end{tabular}

Elio Scarpini, University of Milan, Dino Critical review of manuscript MD Ferrari Center, Italy for intellectual content, contribution of samples and demographics metadata

\begin{tabular}{lll}
\hline $\begin{array}{l}\text { Maria } \\
\text { Serpente, PhD }\end{array}$ & $\begin{array}{l}\text { University of Milan, Dino } \\
\text { Ferrari Center, Italy }\end{array}$ & $\begin{array}{l}\text { Critical review of } \\
\text { manuscript for } \\
\text { intellectual content, } \\
\text { contribution of samples } \\
\text { and demographics } \\
\text { metadata }\end{array}$ \\
\hline Nicoletta & Regional Neurogenetic & $\begin{array}{l}\text { Critical review of } \\
\text { manuscript for } \\
\text { intellectual content, } \\
\text { contribution of samples } \\
\text { and demographics } \\
\text { metadata }\end{array}$ \\
& Centre, ASPCZ, Lamezia \\
\hline
\end{tabular}

\begin{tabular}{lll}
\hline $\begin{array}{l}\text { Sandro Sorbi, } \\
\text { MD }\end{array}$ & $\begin{array}{l}\text { Department of } \\
\text { Neuroscience, } \\
\text { Psychology, Drug } \\
\text { Research and Child } \\
\text { Health, University of } \\
\text { Florence, Italy }\end{array}$ & $\begin{array}{l}\text { Critical review of } \\
\text { manuscript for } \\
\text { intellectual content, } \\
\text { contribution of samples } \\
\text { and demographics } \\
\text { metadata }\end{array}$ \\
\hline $\begin{array}{l}\text { EunRan Suh, } \\
\text { PhD }\end{array}$ & $\begin{array}{l}\text { Department of Pathology } \\
\text { and Laboratory Medicine, } \\
\text { Perelman School of } \\
\text { Medicine at the University } \\
\text { of Pennsylvania, } \\
\text { Philadelphia }\end{array}$ & $\begin{array}{l}\text { Critical review of } \\
\text { manuscript for } \\
\text { intellectual content, } \\
\text { contribution of } \\
\text { samples and } \\
\text { demographics } \\
\text { metadata }\end{array}$ \\
\hline
\end{tabular}

\begin{tabular}{lll}
\hline Fabrizio & Fondazione IRCCS Istituto & Critical review of \\
Tagliavini, MD & Neurologico Carlo Besta, & manuscript for \\
intellectual content, & contribution of \\
& & samples and \\
& & demographics \\
& metadata
\end{tabular}

\begin{tabular}{lll}
\hline Jennifer C. & Manchester Centre for & Critical review of \\
Thompson, & Clinical Neurosciences, & manuscript for intellectual \\
PhD & Salford Royal NHS Trust, & $\begin{array}{l}\text { content, contribution of } \\
\text { samples and demographics } \\
\text { Manchester, UK }\end{array}$ \\
& & metadata \\
\hline
\end{tabular}

\begin{tabular}{|c|c|c|}
\hline $\begin{array}{l}\text { John Q. } \\
\text { Trojanowski, } \\
\text { MD, PhD }\end{array}$ & $\begin{array}{l}\text { Department of Pathology } \\
\text { and Laboratory Medicine, } \\
\text { Perelman School of } \\
\text { Medicine at the University } \\
\text { of Pennsylvania, } \\
\text { Philadelphia }\end{array}$ & $\begin{array}{l}\text { Critical review of } \\
\text { manuscript for } \\
\text { intellectual content, } \\
\text { contribution of } \\
\text { samples and } \\
\text { demographics } \\
\text { metadata }\end{array}$ \\
\hline
\end{tabular}

\begin{tabular}{lll}
\hline Vivianna M. & Department of Pathology & Critical review of \\
Van Deerlin, & and Laboratory Medicine, & manuscript for intellectual \\
MD, PhD & Perelman School of & content, contribution of \\
& Medicine at the University & samples and demographics \\
& of Pennsylvania, & metadata \\
& Philadelphia & \\
\end{tabular}

Appendix 1 (continued)

\begin{tabular}{|c|c|c|}
\hline Name & Location & Contribution \\
\hline $\begin{array}{l}\text { Julie van der } \\
\text { Zee, PhD }\end{array}$ & $\begin{array}{l}\text { Neurodegenerative Brain } \\
\text { Diseases group, Center } \\
\text { for Molecular Neurology, } \\
\text { VIB, Antwerp, Belgium }\end{array}$ & $\begin{array}{l}\text { Critical review of } \\
\text { manuscript for intellectual } \\
\text { content, contribution of } \\
\text { samples and demographics } \\
\text { metadata }\end{array}$ \\
\hline $\begin{array}{l}\text { Christine Van } \\
\text { Broeckhoven, } \\
\text { DSc, PhD }\end{array}$ & $\begin{array}{l}\text { Neurodegenerative Brain } \\
\text { Diseases group, Center } \\
\text { for Molecular Neurology, } \\
\text { VIB, Antwerp, Belgium }\end{array}$ & $\begin{array}{l}\text { Critical review of manuscript } \\
\text { for intellectual content, } \\
\text { contribution of samples and } \\
\text { demographics metadata }\end{array}$ \\
\hline $\begin{array}{l}\text { Jeroen G.J. van } \\
\text { Rooij }\end{array}$ & $\begin{array}{l}\text { Department of } \\
\text { Neurology, Erasmus } \\
\text { Medical Center, } \\
\text { Rotterdam, the } \\
\text { Netherlands }\end{array}$ & $\begin{array}{l}\text { Critical review of } \\
\text { manuscript for } \\
\text { intellectual content, } \\
\text { contribution of samples } \\
\text { and demographics } \\
\text { metadata }\end{array}$ \\
\hline
\end{tabular}

\begin{tabular}{lll}
\hline $\begin{array}{l}\text { John C. van } \\
\text { Swieten, MD, } \\
\text { PhD }\end{array}$ & $\begin{array}{l}\text { Department of } \\
\text { Neurology, Erasmus } \\
\text { Medical Center, } \\
\text { Rotterdam, the } \\
\text { Netherlands }\end{array}$ & $\begin{array}{l}\text { Critical review of } \\
\text { manuscript for intellectual } \\
\text { content, contribution of } \\
\text { samples and demographics } \\
\text { metadata }\end{array}$ \\
\hline $\begin{array}{l}\text { Arianna } \\
\text { Veronesi, MD, } \\
\text { PhD }\end{array}$ & $\begin{array}{l}\text { Cognitive Impairment } \\
\text { Center, Local Health } \\
\text { Authority n.2 Marca } \\
\text { Trevigiana, Treviso, } \\
\text { Italy }\end{array}$ & $\begin{array}{l}\text { Critical review of } \\
\text { manuscript for } \\
\text { intellectual content, } \\
\text { contribution of samples } \\
\text { and demographics } \\
\text { metadata }\end{array}$ \\
\end{tabular}

Emilia Vitale, NeurOMICS laboratory, Critical review of

PhD Institute of Biochemistry manuscript for intellectual and Cell Biology (IBBC), content, contribution of CNR Napoli, Italy samples and demographics metadata

\begin{tabular}{lll}
\hline Maria L. & Division of Clinical & Critical review of \\
Waldö, MD, & Sciences Helsingborg, & manuscript for \\
PhD & Department of Clinical & intellectual content, \\
& Sciences Lund, Lund & contribution of samples \\
& University, Sweden & $\begin{array}{l}\text { and demographics } \\
\text { metadata }\end{array}$
\end{tabular}

\begin{tabular}{|c|c|c|}
\hline $\begin{array}{l}\text { Cathy } \\
\text { Woodward, } \\
\text { MSc }\end{array}$ & $\begin{array}{l}\text { Neurogenetics } \\
\text { Laboratory, National } \\
\text { Hospital for Neurology } \\
\text { and Neurosurgery, } \\
\text { London, UK }\end{array}$ & $\begin{array}{l}\text { C9orf72 expansions } \\
\text { screening, data } \\
\text { interpretation and } \\
\text { drafting of } \\
\text { manuscript }\end{array}$ \\
\hline $\begin{array}{l}\text { Jennifer S. } \\
\text { Yokoyama, } \\
\text { PhD }\end{array}$ & $\begin{array}{l}\text { Department of } \\
\text { Neurology, Memory and } \\
\text { Aging Center, University } \\
\text { of California, San } \\
\text { Francisco }\end{array}$ & $\begin{array}{l}\text { Critical review of } \\
\text { manuscript for intellectual } \\
\text { content, contribution of } \\
\text { samples and demographics } \\
\text { metadata }\end{array}$ \\
\hline $\begin{array}{l}\text { Valentina } \\
\text { Escott-Price, } \\
\text { PhD }\end{array}$ & $\begin{array}{l}\text { Medical Research Council } \\
\text { Centre for Neuropsychiatric } \\
\text { Genetics and Genomics, } \\
\text { Division of Psychological } \\
\text { Medicine and Clinical } \\
\text { Neurosciences, Cardiff } \\
\text { University, UK and Dementia } \\
\text { Research Institute, Cardiff } \\
\text { University, UK }\end{array}$ & $\begin{array}{l}\text { Project design, data } \\
\text { analyses and } \\
\text { interpretation, } \\
\text { manuscript drafting }\end{array}$ \\
\hline $\begin{array}{l}\text { James M. } \\
\text { Polke, PhD }\end{array}$ & $\begin{array}{l}\text { Neurogenetics Laboratory, } \\
\text { National Hospital for } \\
\text { Neurology and } \\
\text { Neurosurgery, London, UK }\end{array}$ & $\begin{array}{l}\text { C9orf72 expansions } \\
\text { screening, data } \\
\text { interpretation and } \\
\text { drafting of manuscript }\end{array}$ \\
\hline $\begin{array}{l}\text { Raffaele } \\
\text { Ferrari, PhD }\end{array}$ & $\begin{array}{l}\text { Department of } \\
\text { Neurodegenerative } \\
\text { Disease, University } \\
\text { College London, Institute } \\
\text { of Neurology, UK }\end{array}$ & $\begin{array}{l}\text { Project design, data } \\
\text { analyses and } \\
\text { interpretation, } \\
\text { manuscript drafting }\end{array}$ \\
\hline
\end{tabular}


Appendix 2 Coinvestigators

Coinvestigators are listed at links.Iww.com/WNL/B240

\section{References}

1. Ratnavalli E, Brayne C, Dawson K, Hodges JR. The prevalence of frontotemporal dementia. Neurology 2002;58:1615-1621.

2. Neary D, Snowden JS, Gustafson L, et al. Frontotemporal lobar degeneration: a consensus on clinical diagnostic criteria. Neurology 1998;51:1546-1554.

3. Gorno-Tempini ML, Hillis AE, Weintraub S, et al. Classification of primary progressive aphasia and its variants. Neurology 2011;76:1006-1014.

4. Strong MJ, Abrahams S, Goldstein LH, et al. Amyotrophic lateral sclerosisfrontotemporal spectrum disorder (ALS-FTSD): revised diagnostic criteria. Amyotroph Lateral Scler Frontotemporal Degener 2017;18:153-174.

5. Babić Leko M, Zupunski V, Kirincich J, et al. Molecular mechanisms of neurodegeneration related to $\mathrm{C} 9$ orf72 hexanucleotide repeat expansion. Behav Neurol 2019;2019:2909168.

6. DeJesus-Hernandez M, Mackenzie IR, Boeve BF, et al. Expanded GGGGCC hexanucleotide repeat in noncoding region of C9ORF72 causes chromosome 9p-linked FTD and ALS. Neuron 2011;72:245-256.

7. Ferrari R, Manzoni C, Hardy J. Genetics and molecular mechanisms of frontotemporal lobar degeneration: an update and future avenues. Neurobiol Aging 2019;78:98-110.

8. Pottier C, Ravenscroft TA, Sanchez-Contreras M, Rademakers R. Genetics of FTLD: overview and what else we can expect from genetic studies. J Neurochem 2016; 138(suppl 1):32-53.

9. Seelaar H, Rohrer JD, Pijnenburg YA, Fox NC, van Swieten JC. Clinical, genetic and pathological heterogeneity of frontotemporal dementia: a review. J Neurol Neurosurg Psychiatry 2011;82:476-486

10. van der Zee J, Gijselinck I, Dillen L, et al. A Pan-European study of the C9orf72 repeat associated with FTLD: geographic prevalence, genomic instability, and intermediate repeats. Hum Mutat 2013;34:363-373.

11. LT T. The genetics of monogenic frontotemporal dementia. Dement Neuropsychol 2015:219-229.

12. Turner MR, Al-Chalabi A, Chio A, et al. Genetic screening in sporadic ALS and FTD J Neurol Neurosurg Psychiatry 2017;88:1042-1044.

13. Majounie E, Renton AE, Mok K, et al. Frequency of the C9orf72 hexanucleotide repeat expansion in patients with amyotrophic lateral sclerosis and frontotemporal dementia: a cross-sectional study. Lancet Neurol 2012;11:323-330.

14. Ramos EM, Koros C, Dokuru DR, et al. Frontotemporal dementia spectrum: first genetic screen in a Greek cohort. Neurobiol Aging 2019;75:224.e221-224.e228.

15. Mok K, Traynor BJ, Schymick J, et al. Chromosome 9 ALS and FTD locus is probably derived from a single founder. Neurobiol Aging 2012;33:209.e203-209.e208.

16. Beck J, Poulter M, Hensman D, et al. Large C9orf 72 hexanucleotide repeat expansions are seen in multiple neurodegenerative syndromes and are more frequent than expected in the UK population. Am J Hum Genet 2013;92:345-353.

17. Chiang $\mathrm{HH}$, Forsell C, Lindstrom AK, et al. No common founder for C9orf72 expansion mutation in Sweden. J Hum Genet 2017;62:321-324.

18. Fratta P, Polke JM, Newcombe J, et al. Screening a UK amyotrophic lateral sclerosis cohort provides evidence of multiple origins of the C9orf72 expansion. Neurobiol Aging 2015;36:546 e541-547.
19. Xi Z, van Blitterswijk $M$, Zhang $\mathrm{M}$, et al. Jump from pre-mutation to pathologic expansion in C9orf72. Am J Hum Genet 2015;96:962-970.

20. Van Mossevelde S, Engelborghs S, van der Zee J, Van Broeckhoven C. Genotypephenotype links in frontotemporal lobar degeneration. Nat Rev Neurol 2018;14: 363-378.

21. Fournier C, Barbier M, Camuzat A, et al. Relations between C9orf72 expansion size in blood, age at onset, age at collection and transmission across generations in patients and presymptomatic carriers. Neurobiol Aging 2019;74:234.e231-234.e238.

22. Gijselinck I, Van Mossevelde S, van der Zee J, et al. The C9orf72 repeat size correlates with onset age of disease, DNA methylation and transcriptional downregulation of the promoter. Mol Psychiatry 2016;21:1112-1124.

23. van Blitterswijk M, Dejesus-Hernandez M, Niemantsverdriet E, et al. Association between repeat sizes and clinical and pathological characteristics in carriers of C9ORF72 repeat expansions (Xpansize-72): a cross-sectional cohort study. Lancet Neurol 2013;12:978-988

24. Van Mossevelde S, van der Zee J, Gijselinck I, et al. Clinical evidence of disease anticipation in families segregating a C9orf72 repeat expansion. JAMA Neurol 2017;74:445-452.

25. Rascovsky K, Hodges JR, Knopman D, et al. Sensitivity of revised diagnostic criteria for the behavioural variant of frontotemporal dementia. Brain 2011;134: 2456-2477.

26. Blauwendraat C, Faghri F, Pihlstrom L, et al. NeuroChip, an updated version of the NeuroX genotyping platform to rapidly screen for variants associated with neurological diseases. Neurobiol Aging 2017;57:247 e249-247 e213.

27. Ferrari R, Mok K, Moreno JH, et al. Screening for C9ORF72 repeat expansion in FTLD. Neurobiol Aging 2012;33:1850.e1-e11.

28. Renton $\mathrm{AE}$, Majounie $\mathrm{E}$, Waite $\mathrm{A}$, et al. A hexanucleotide repeat expansion in C9ORF72 is the cause of chromosome 9p21-linked ALS-FTD. Neuron 2011;72: 257-268.

29. Laaksovirta H, Peuralinna T, Schymick JC, et al. Chromosome 9p21 in amyotrophic lateral sclerosis in Finland: a genome-wide association study. Lancet Neurol 2010;9: 978-985.

30. Benussi L, Rossi G, Glionna M, et al. C9ORF72 hexanucleotide repeat number in frontotemporal lobar degeneration: a genotype-phenotype correlation study. J Alzheimers Dis 2015;45:319.

31. Devenney E, Bartley L, Hoon C, et al. Progression in behavioral variant frontotemporal dementia: a longitudinal study. JAMA Neurol 2015;72:1501-1509.

32. Galimberti D, Fenoglio C, Serpente M, et al. Autosomal dominant frontotemporal lobar degeneration due to the C9ORF72 hexanucleotide repeat expansion: late-onset psychotic clinical presentation. Biol Psychiatry 2013;74:384-391.

33. Ramos EM, Dokuru DR, Van Berlo V, et al. Genetic screen in a large series of patients with primary progressive aphasia. Alzheimers Dement 2019;15:553-560.

34. Simon-Sanchez J, Dopper EG, Cohn-Hokke PE, et al. The clinical and pathologica phenotype of C9ORF72 hexanucleotide repeat expansions. Brain 2012;135:723-735

35. Ralph P, Coop G. The geography of recent genetic ancestry across Europe. PLoS Biol 2013;11:e1001555.

36. Warby SC, Montpetit A, Hayden AR, et al. CAG expansion in the Huntington disease gene is associated with a specific and targetable predisposing haplogroup. Am J Hum Genet 2009;84:351-366.

37. Huang T, Shu Y, Cai YD. Genetic differences among ethnic groups. BMC Genomics 2015;16:1093.

38. Zhang M, Ferrari R, Tartaglia MC, et al. A C6orf10/LOC101929163 locus is associated with age of onset in C9orf72 carriers. Brain 2018;141:2895-2907. 


\section{Neurology}

\section{C9orf72, age at onset, and ancestry help discriminate behavioral from language variants in FTLD cohorts \\ Beatrice Costa, Claudia Manzoni, Manuel Bernal-Quiros, et al.}

Neurology 2020;95;e3288-e3302 Published Online before print September 17, 2020

DOI 10.1212/WNL.0000000000010914

This information is current as of September 17, 2020

\section{Updated Information \&} Services

References

Subspecialty Collections

Permissions \& Licensing

Reprints including high resolution figures, can be found at: http://n.neurology.org/content/95/24/e3288.full

This article cites 37 articles, 5 of which you can access for free at: http://n.neurology.org/content/95/24/e3288.full\#ref-list-1

This article, along with others on similar topics, appears in the following collection(s):

\section{All Genetics}

http://n.neurology.org/cgi/collection/all_genetics

Frontotemporal dementia

http://n.neurology.org/cgi/collection/frontotemporal_dementia

Information about reproducing this article in parts (figures,tables) or in its entirety can be found online at:

http://www.neurology.org/about/about_the_journal\#permissions

Information about ordering reprints can be found online:

http://n.neurology.org/subscribers/advertise

Neurology ${ }^{\circledR}$ is the official journal of the American Academy of Neurology. Published continuously since 1951, it is now a weekly with 48 issues per year. Copyright Copyright ( 2020 The Author(s). Published by Wolters Kluwer Health, Inc. on behalf of the American Academy of Neurology.. All rights reserved. Print ISSN: 0028-3878. Online ISSN: 1526-632X.

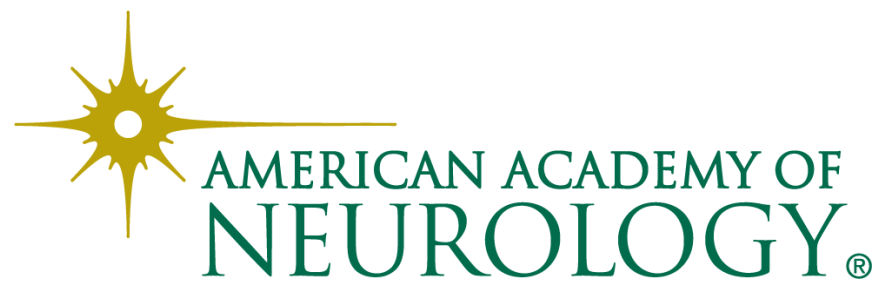

